\title{
Labor market and natural rate of unemployment in US and Canadian time series analysis
}

\section{Dushko Josheski (dushkojosheski@gmail.com)}

Darko Lazarov (darko.lazarov@ugd.edu.mk)

\begin{abstract}
Canadian labor market data are being used in this paper. These series are quarterly data from 1980 Q1 to 2000 Q4. This series are stationary by test for cointegration I(0), meaning that there exist equilibrium relationship between the time series labour productivity (prod), employment (e), unemployment rate (U), real wages (rw). This notion was definitively confirmed with VEC model. VEC model shows long run coefficient, and if the system is in disequilibrium , alteration of the variables will only be -0.003 for real wages or $-0.3 \%,-0.001$ for unemployment or $-0.1 \%,-0.000$ for productivity or $-0 \%$, and $-0 \%$ for employment. This means that Canadian labour market is in equilibrium working at natural rate of unemployment and by equilibrium wages.
\end{abstract}

Key words: employment, real wages, labour productivity, VAR , VECM 


\section{$\underline{\text { Long-run Unemployment }}$}

Unemployment is one of harder and more severe macroeconomic problems for many reasons. First, the loss of a job causes reduction of income and living standard. Second, unemployment is not only macroeconomic problem, but it is social problem, that interested the society at whole. The unemployment is subject of interest especially for politicians, and the problem of unemployment is usually central topic of political debate. In that regard, economic researchers try to find out the causes of unemployment, and the policy makers try to create and implement policies that will reduce the number of unemployed.

The rate of unemployment is a stock variable that can be measured at a given point in time, and show how many people from the whole size of the population of working age (labour force) are unemployed. The labor force is the sum of the employed and the unemployed:

$$
L=E+U_{1}
$$

In this regard, the rate of unemployment is:

$$
u=U / L^{2}
$$

\section{The steady-state rate of unemployment}

In this section we will try to explain the factors which determine the natural rate of unemployment throughout creating the model of labour-force. Labour market is specific market in which some people find new job and other lost their jobs. Because our focus is determines of unemployment rate, we assume that the labour force is fixed, and our interest is

\footnotetext{
${ }^{1} L=\pi P \Rightarrow L=\pi^{w} P^{w}+\pi^{m} P^{m}$, where $P$ is the size of population of working age, $\pi$ is participation rate, $P^{w}$ is the size of women of working age, $P^{m}$ is the size of man of working age, $\pi^{w}$ is participation rate of women, and $\pi^{m}$ is participation rate of man.

${ }^{2}$ Multiply with $100 \%$, because all rates, including rate of unemployment is expressed in percentage.
} 
the transition of people in the labour force between employed and unemployed. In the picture below we illustrate the previous statement. The rate of job separation $s$ is the fraction of employed individuals who lose their job each month (or every quarter), the rate of job finding $f$ is the fraction of unemployed individuals who find a job each month (or every quarter). Together, the rate of job separation $s$ and the rate of job finding $f$ determine the rate of unemployment.

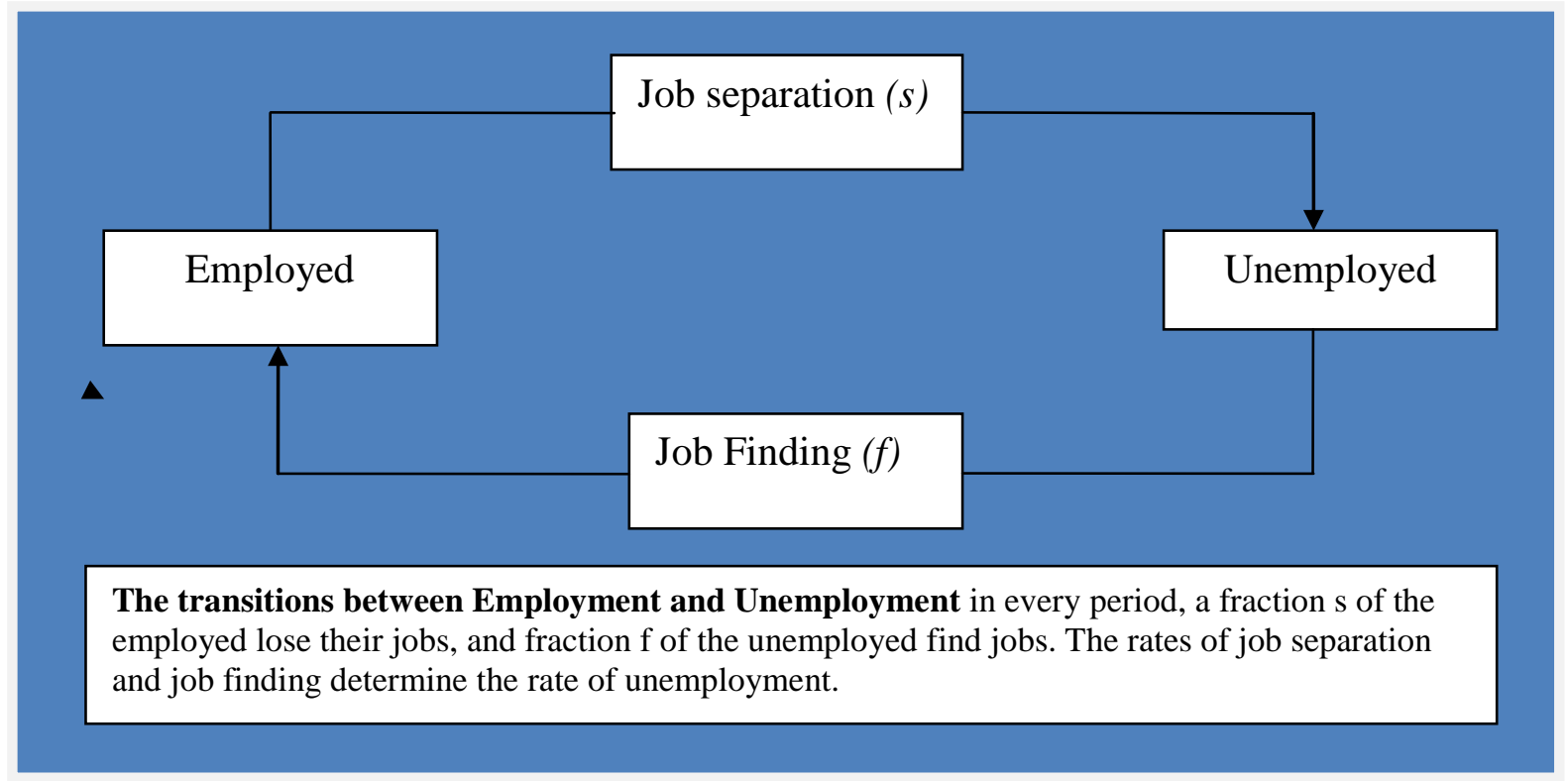

If the unemployment rate is nearly stable, that means, if the labor market is in a steady state-than the number of people finding job s must equal the number of people losing jobs. The number of people finding jobs is $f U$, the number of people losing jobs is $s E$, so we can write the steady state as

$$
\begin{aligned}
& f U=s E \Rightarrow 3 \\
& f U=s(L-U)
\end{aligned}
$$

To solving the mathematical equation for the rate of unemployment, we divide both sides of equation by $L$ to obtain:

\footnotetext{
${ }^{3}$ Form previous equation, $L=E+U \Rightarrow E=L-U$.
} 


$$
f \frac{U}{L}=s\left(1-\frac{U}{L}\right)
$$

Now we can solve for $\frac{U}{L}$ to find

$$
\frac{U}{L}=\frac{s}{s+f} 4
$$

From this equation we can conclude that the steady-state rate of unemployment $u=U / L$ depends on the rates of job separation and job finding. That means when the rate of job separation increase, the rate of unemployment also increases. On the other hand, when the rate of job finding increase, the rate of unemployment decrease.

In addition, we will present empirical estimation for natural rate of unemployment by job fining and job separation.

$$
\begin{aligned}
& u=\frac{U}{L}=\frac{7,29}{7,29+8,20} \\
& =8,18
\end{aligned}
$$

The rate of unemployment in American (first quarter of 1995) is 8.18 percent.

$$
\begin{aligned}
& u=\frac{U}{L}=\frac{6,69}{6,69+7,115} \\
& =7,63
\end{aligned}
$$

The rate of unemployment in American (first quarter of 2005) is 7.63 percent.

4 Mathematical note: If in equation $f \frac{U}{L}=s\left(1-\frac{U}{L}\right)$ we substitute $(E+U)$ for $L$, we find $f \frac{U}{L}=s\left(1-\frac{U}{E+U}\right) \Rightarrow f \frac{U}{L}=s\left(\frac{E+U-U}{E+U}\right)$ if we substitute $\frac{s}{f} E$ for $U$, in the right side of the equation, we obtain: $f \frac{U}{L}=s\left(\frac{E}{E+\frac{s}{f} E}\right)$ we can rearrange the equation $f \frac{U}{L}=s\left(\frac{E}{E\left(\frac{f+s}{f}\right)}\right)$, for $\frac{U}{L}$ the final equation is: $\frac{U}{L}=\frac{s}{s+f}$.

\footnotetext{
${ }^{5}$ These estimations are based on data for American economy.
} 
Tabel.1 Natural rate of unemployment (steady-state unemployment rate) ${ }^{6}$

\begin{tabular}{|c|c|c|c|}
\hline $\begin{array}{l}\text { year/ } \\
\text { quarter }\end{array}$ & job finding $(f)$ & job separation (s) & $\begin{array}{l}\text { rate of unemployment } \\
\text { (r) }\end{array}$ \\
\hline $1995 / 1$ & 8,20 & 7,29 & 8,18 \\
\hline $1995 / 2$ & 8,01 & 7,67 & 8,62 \\
\hline $1995 / 3$ & 8,11 & 7,48 & 8,40 \\
\hline $1995 / 4$ & 8,26 & 7,62 & 8,54 \\
\hline $1996 / 1$ & 8,11 & 7,72 & 8,68 \\
\hline $1996 / 2$ & 8,24 & 7,59 & 8,51 \\
\hline $1996 / 3$ & 8,20 & 7,68 & 8,61 \\
\hline $1996 / 4$ & 8,28 & 7,40 & 8,30 \\
\hline $1997 / 1$ & 8,24 & 7,41 & 8,31 \\
\hline $1997 / 2$ & 8,00 & 7,44 & 8,37 \\
\hline $1997 / 3$ & 8,43 & 7,64 & 8,55 \\
\hline $1997 / 4$ & 8,47 & 7,77 & 8,69 \\
\hline $1998 / 1$ & 8,42 & 7,74 & 8,65 \\
\hline $1998 / 2$ & 8,43 & 7,71 & 8,63 \\
\hline $1998 / 3$ & 8,18 & 7,53 & 8,45 \\
\hline $1998 / 4$ & 8,11 & 7,44 & 8,36 \\
\hline $1999 / 1$ & 8,25 & 7,95 & 8,92 \\
\hline $1999 / 2$ & 8,29 & 7,70 & 8,63 \\
\hline $1999 / 3$ & 8,30 & 7,69 & 8,61 \\
\hline $1996 / 4$ & 8,44 & 7,52 & 8,41 \\
\hline $2000 / 1$ & 8,14 & 7,42 & 8,33 \\
\hline $2000 / 2$ & 8,00 & 7,53 & 8,47 \\
\hline $2000 / 3$ & 8,01 & 7,73 & 8,69 \\
\hline $2000 / 4$ & 7,85 & 7,60 & 8,57 \\
\hline $2001 / 1$ & 7,71 & 7,94 & 8,97 \\
\hline $2001 / 2$ & 7,52 & 8,16 & 9,24 \\
\hline $2001 / 3$ & 7,27 & 8,25 & 9,39 \\
\hline $2001 / 4$ & 7,31 & 8,20 & 9,32 \\
\hline $2002 / 1$ & 7,53 & 7,60 & 8,61 \\
\hline $2002 / 2$ & 7,45 & 7,54 & 8,55 \\
\hline $2002 / 3$ & 7,36 & 7,32 & 8,32 \\
\hline $2002 / 4$ & 7,13 & 7,40 & 8,44 \\
\hline $2003 / 1$ & 7,02 & 7,41 & 8,46 \\
\hline $2003 / 2$ & 7,04 & 7,24 & 8,27 \\
\hline $2003 / 3$ & 7,06 & 6,76 & 7,72 \\
\hline $2003 / 4$ & 7,08 & 6,88 & 7,86 \\
\hline $2004 / 1$ & 7,31 & 6,81 & 7,75 \\
\hline $2004 / 2$ & 7,22 & 6,79 & 7,73 \\
\hline $2004 / 3$ & 7,30 & 6,94 & 7,90 \\
\hline $2004 / 4$ & 7,34 & 6,70 & 7,61 \\
\hline $2005 / 1$ & 7,11 & 6,69 & 7,63 \\
\hline
\end{tabular}

\footnotetext{
${ }^{6}$ The estimation is based on data from The flow approach to Labor markets: Davis, Faberman and Haltiwanger (2006, Journal of Economic Perspectives)
} 
Picture1.The natural rate of unemployment flow

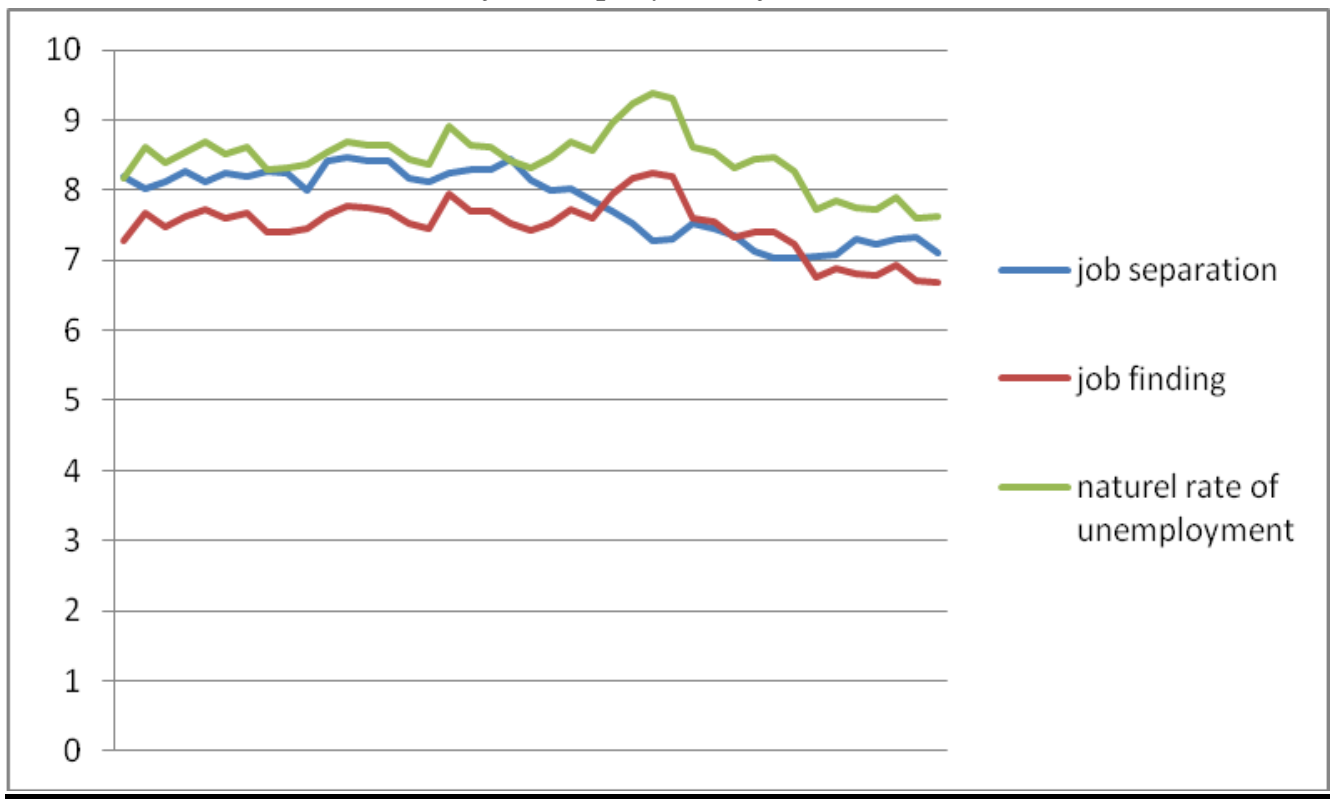

\section{Data description}

In this paper we use Canadian time series for, labour productivity (prod), employment (e), unemployment rate $(\mathrm{U})$, real wages (rw).

Original time series are from OECD database, OECD Main Economic Indicators:

$>$ 444113DSA Canadian unemployment rate in \%

$>444321 \mathrm{KSA}$ Canadian manufacturing real wage index

$>445241 \mathrm{~K}$ Canadian consumer price index

$>$ OECD Quarterly National Accounts:

$>$ CAN1008S1 Canadian nominal GDP

$>$ OECD Quarterly Labour Force Statistics:

$>$ 445005DSA Canadian civilian employment in 1000 persons

The data included in this file are obtained by the following transformations:

$\operatorname{prod}=100 *(\log (\mathrm{CAN} 1008 \mathrm{~S} 1 / 445241 \mathrm{~K})-\log (445005 \mathrm{DSA}))$

$\mathrm{e}=100 * \log (445005 \mathrm{DSA})$

$\mathrm{U}=444113 \mathrm{DSA}$

$\mathrm{rw} \quad=100 * \log (100 * 444321 \mathrm{KSA})$ 
Plot of time series

On the next page it is presented plot of time series data. This is for purpose of visual inspection of the data and to see their movement across time. These series are quarterly data from 1980 Q1 to 2000 Q4

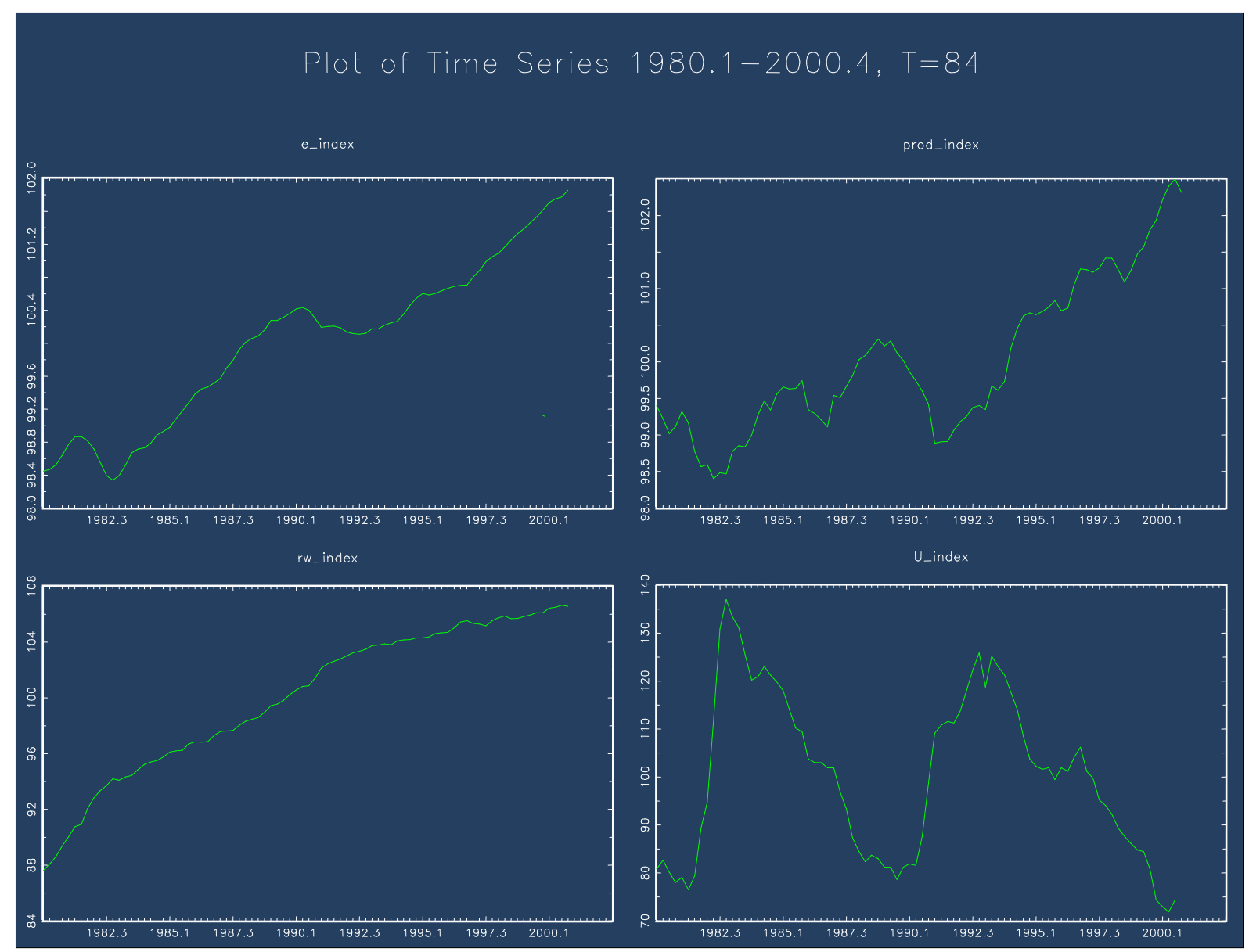

escriptive statistics

Descriptive statistics reports standard minimum,maximum and standard deviation.
sample range: $\quad[1980 \mathrm{Q} 1,2000 \mathrm{Q} 4], \mathrm{T}=84$
DESCRIPTIVE STATISTICS :
variable
mean
$\min$
$\max$
std. dev.
e
$9.44257 e+02$
$9.28563 e+02$
$9.61766 e+02$
$9.10304 \mathrm{e}+00$ 
Plot of complete time series

On the next page is presented plot of complete time series data.

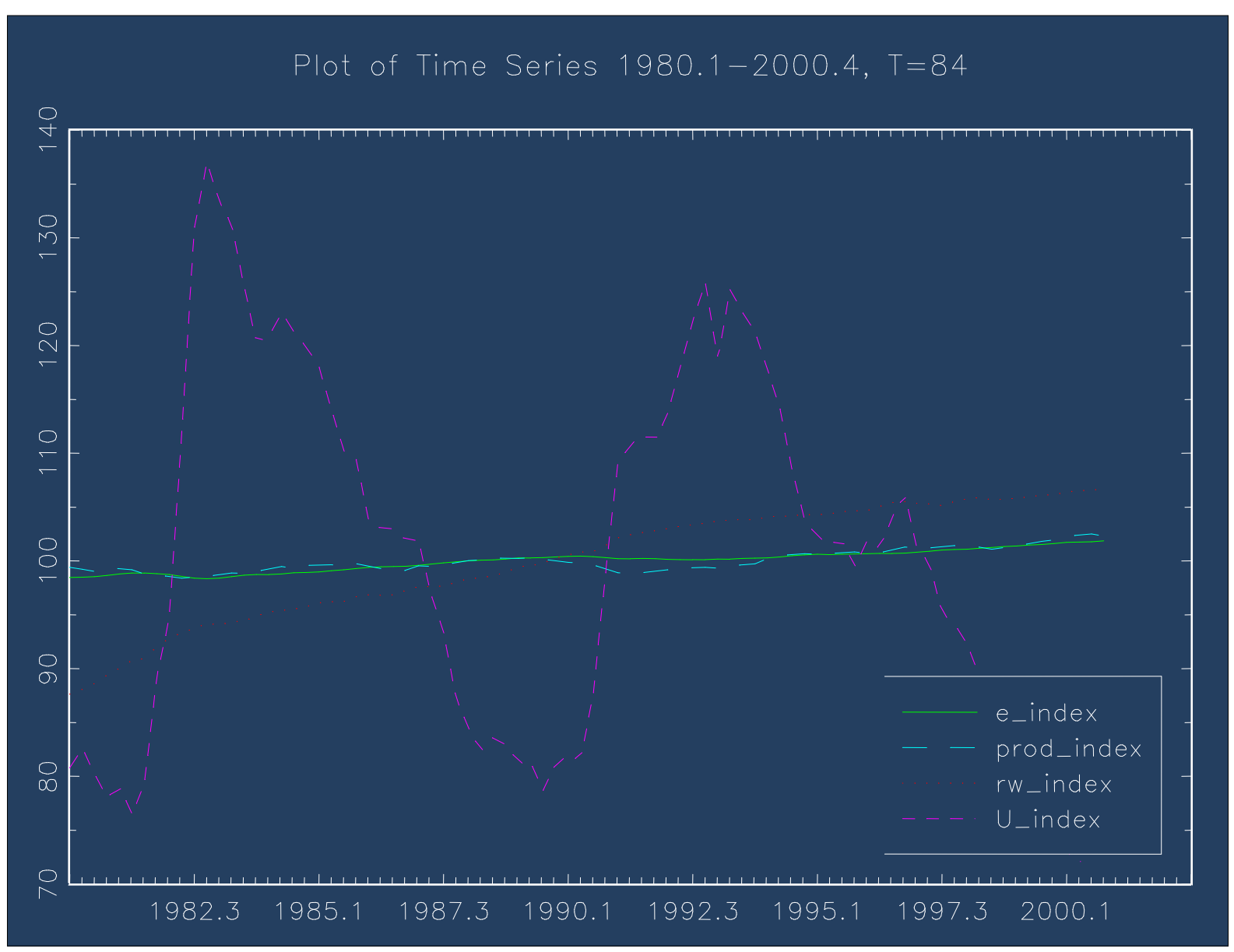


Test for normality and heteroscedasticity

Standard Jarque-Bera test for non-normality and test for heteroscedasticity ARCH-LM test will be applied.

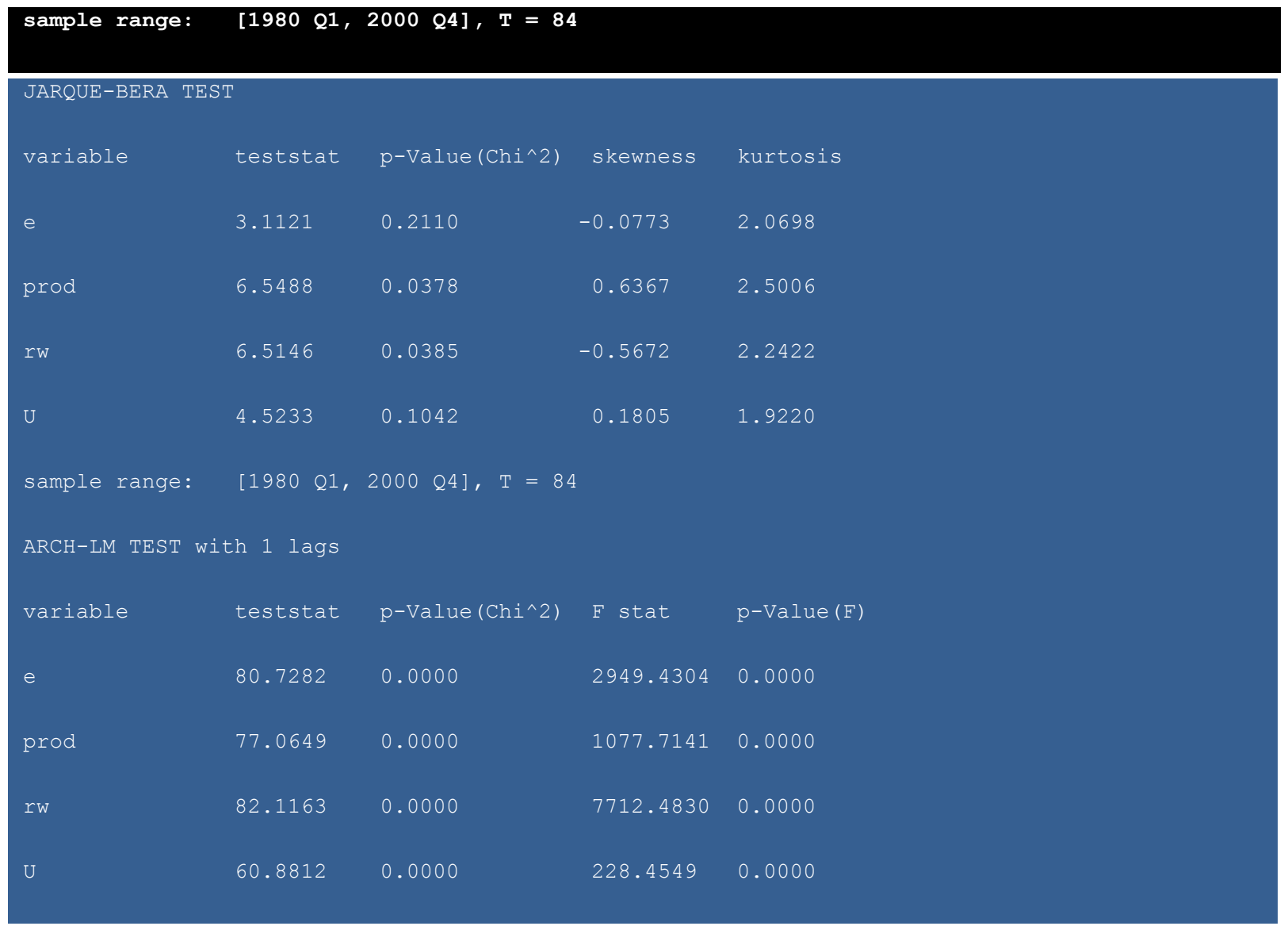

Normality and heteroscdasticity are not serious problem with time series data .

\section{Nadaraya-Watson OLS regression}

Next it is presented OLS regression of labour productivity on Real wages. The relationship between variables is positive and significant. This regression is presented graphically by crossplot (see Crossplot (rw)). 


\section{OLS ESTIMATION}

sample range: $\quad[1980$ Q1, 2000 Q4], T $=84$

dependent: prod

independent : $\quad r w$

prod $=348.0978+0.1355 \star r w$

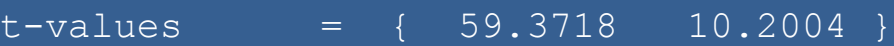

sigma $\quad=2.8163$

R-squared $\quad=0.5593$

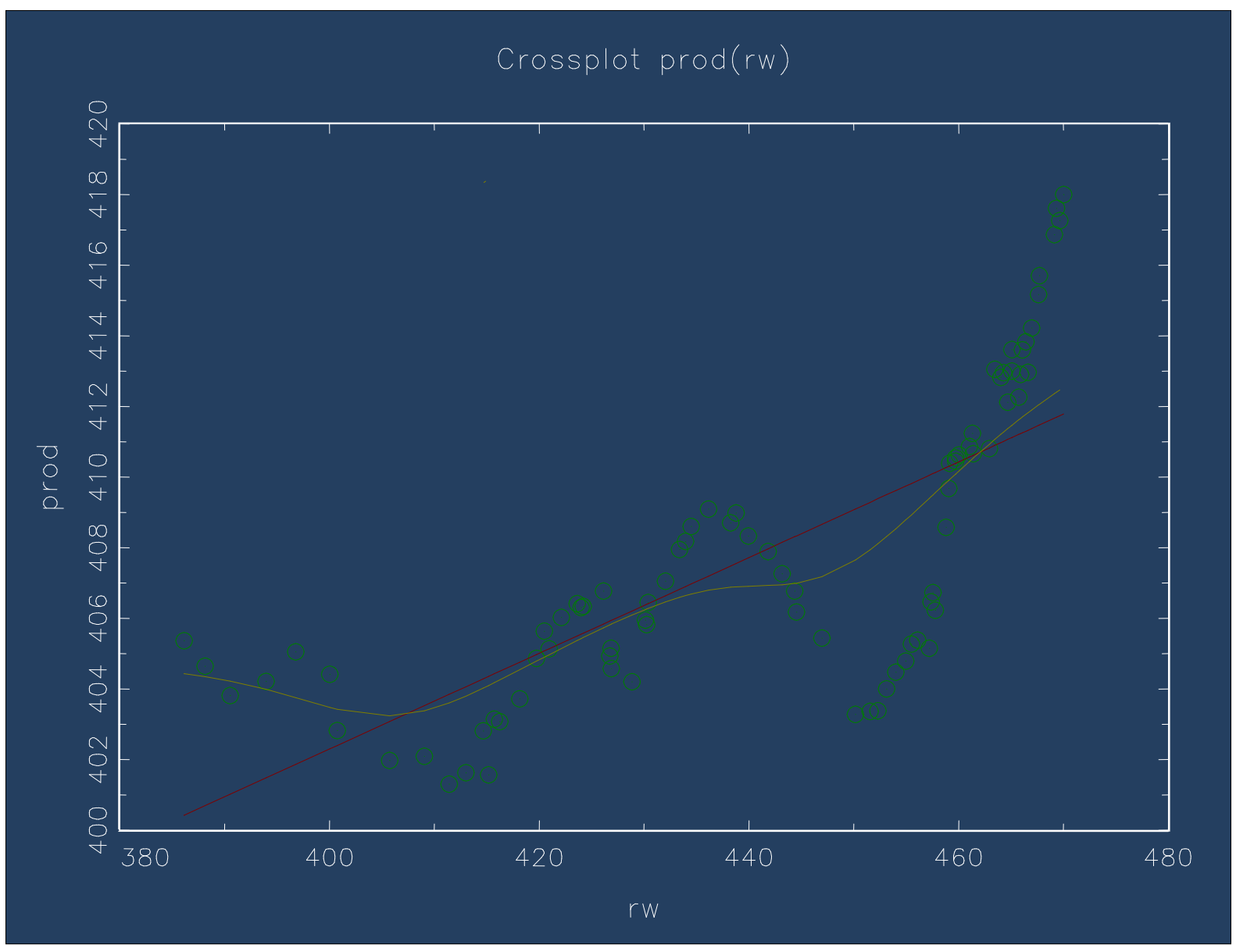




\section{OLS ESTIMATION PRODUCTIVITY VERSUS UNEMPLYMENT}

OLS estimation is done on labour productivity versus unemployment and the result is negative and significant. This crossplot is given below OLS table.

\section{OLS ESTIMATION}

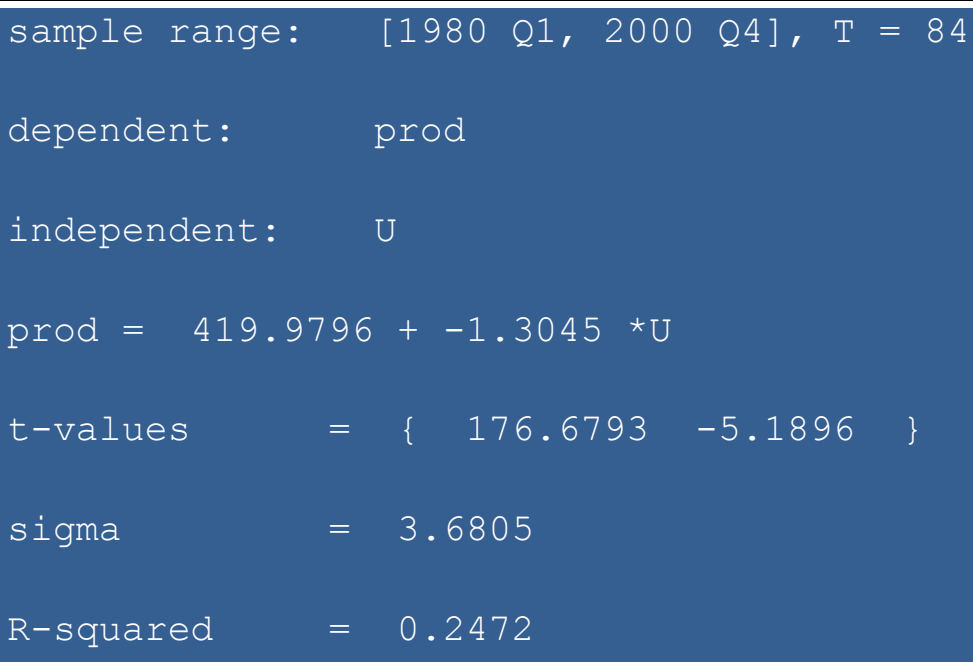




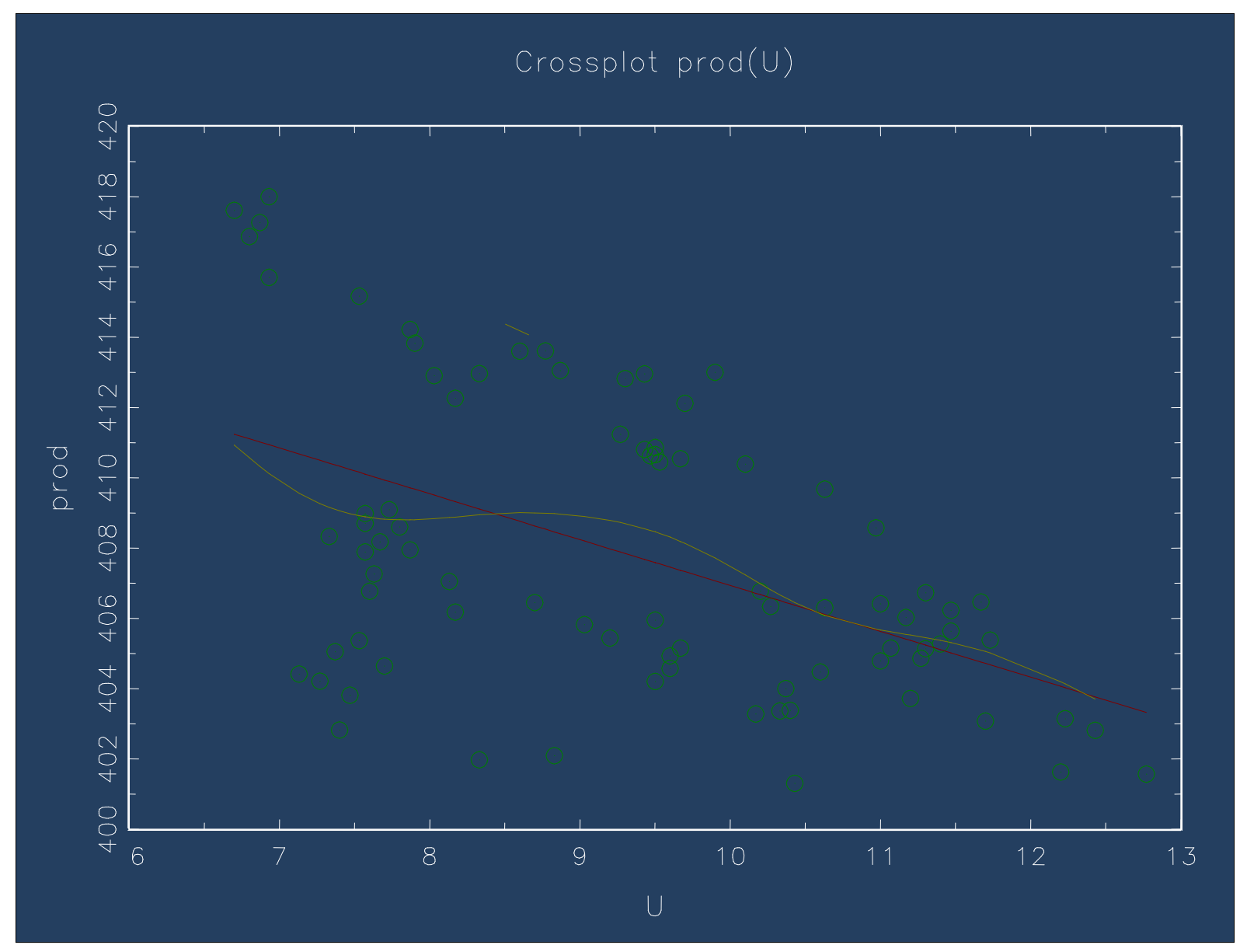

\section{$\underline{\text { OLS regression Employment vs real wages }}$}

Result is presented below and the result is positive and significant. Crossplot of the regression is presented below the OLS table.

\section{OLS ESTIMATION}

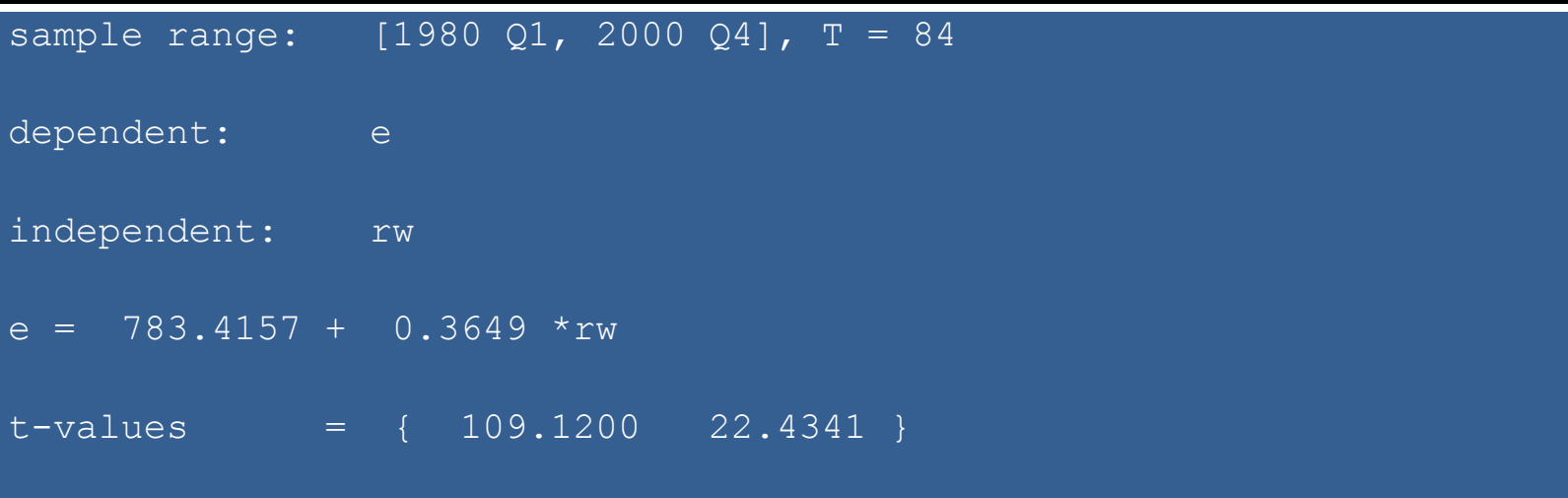




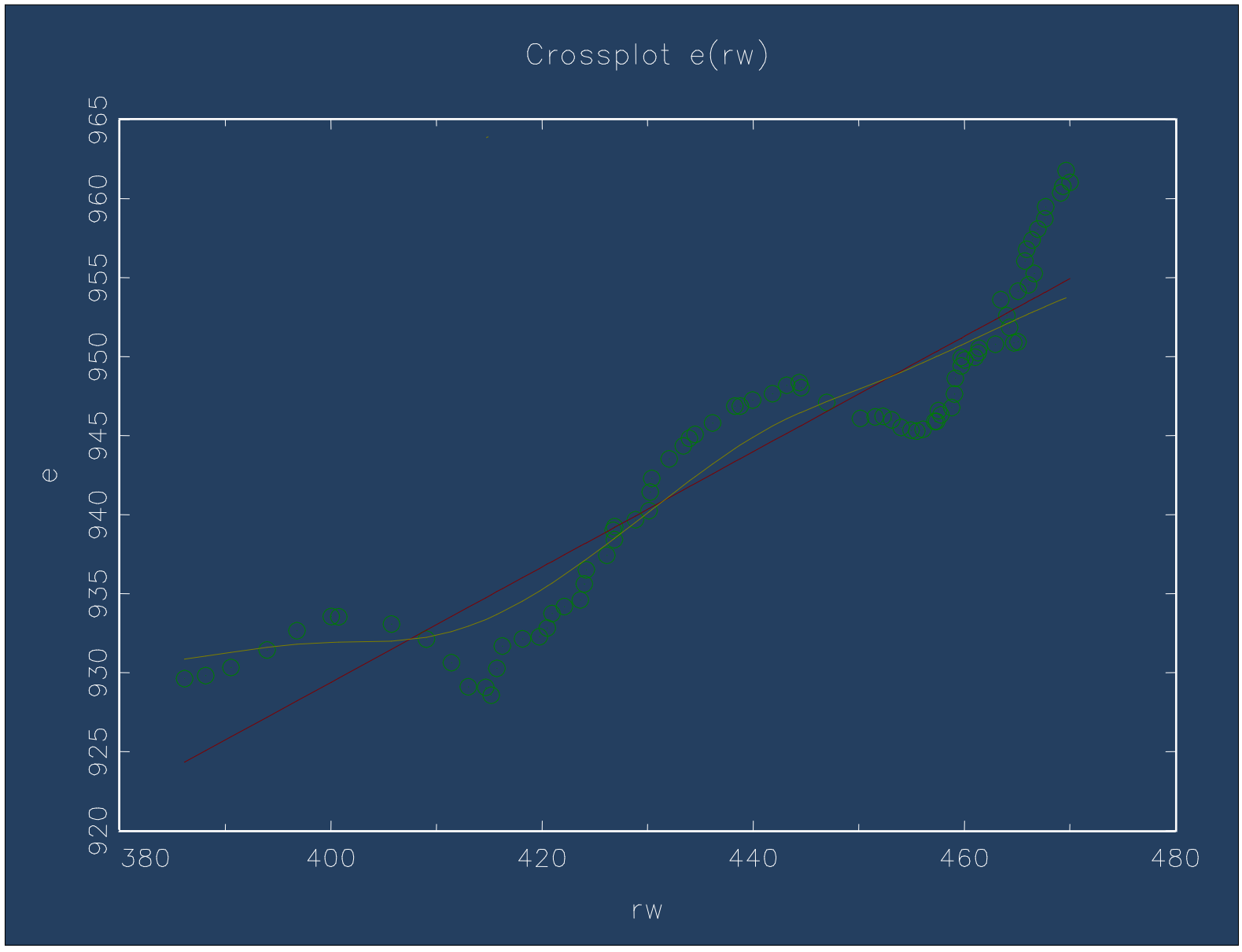

\section{ADF TESTS FOR TIME SERIES}

ADF test have been preformed to prove whether time series are stationary.

ADF unit root test for employment

ADF Test for series:

e

sample range:

$[1980$

Q4,

2000 Q4], $\mathrm{T}=81$ 


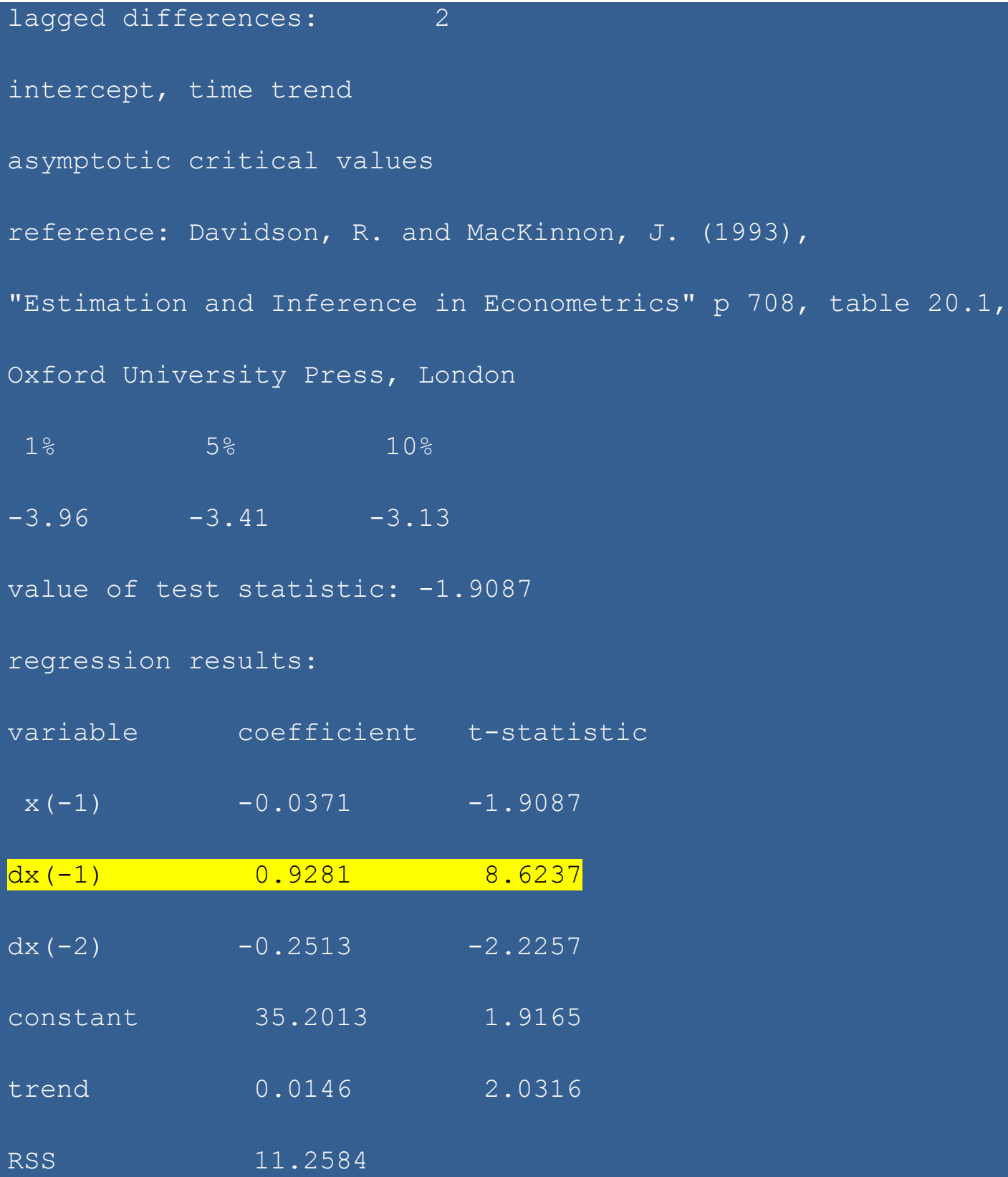

\section{OPTIMAL ENDOGENOUS IAGS FROM INFORMATION CRITERIA}

sample range: $\quad[1982 \mathrm{Q} 4,2000 \mathrm{Q4}], \mathrm{T}=73$

optimal number of lags (searched up to 10 lags of 1 . differences):

Akaike Info Criterion

Hannan-Quinn Criterion 
This variable is first difference stationary. Optimal number of lags by info criteria is $(1,9)$.

\section{$\underline{\text { Test for cointegration }}$}

Johansens trace test for cointegration is being delivered for employment variable.

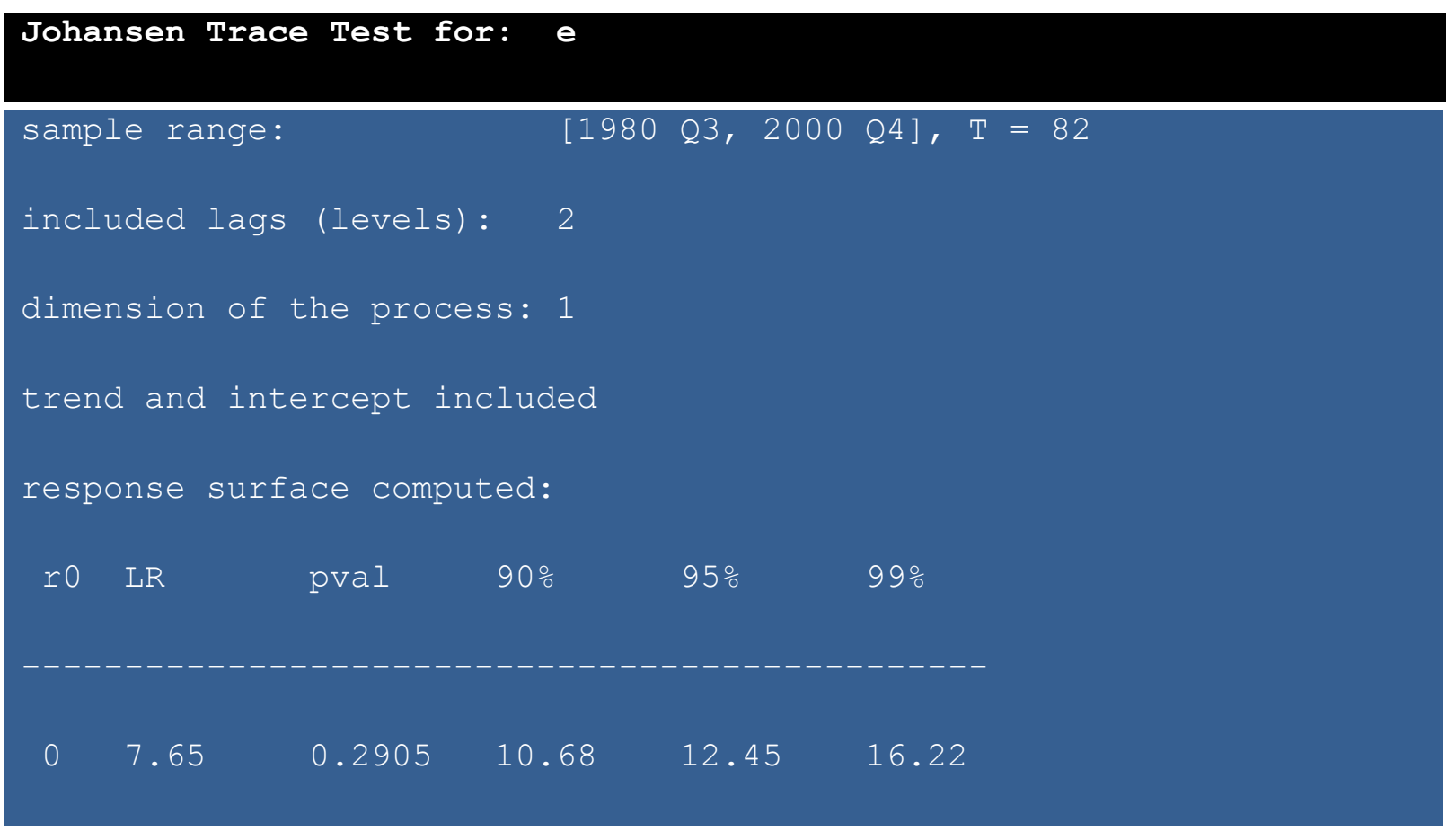


This variable employment, is I $(0)$ variable , meaning that is stationary at fist difference.

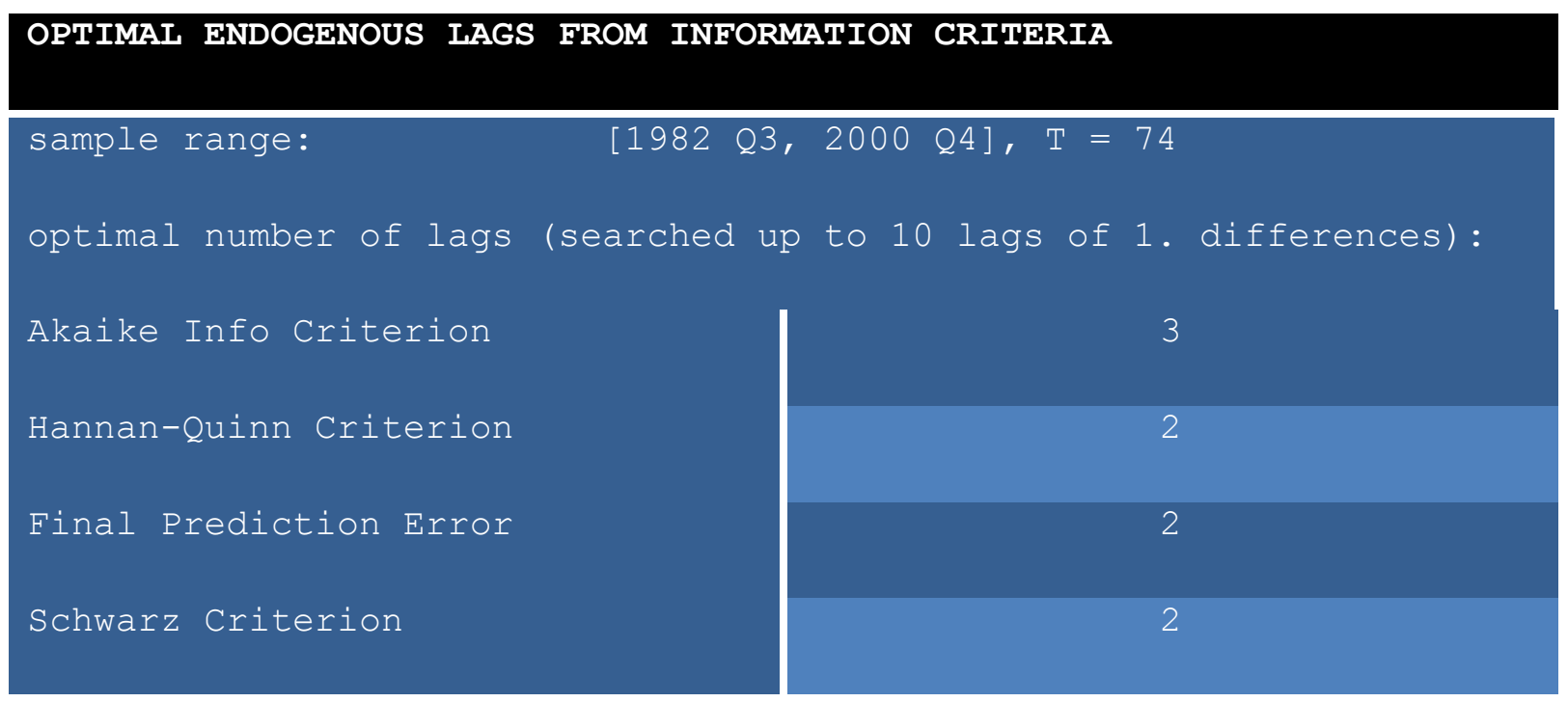

Optimal number of lags according to info criteria is 2 .

\section{$\underline{\mathrm{ADF} \text { test for labour productivity }}$}

In the next table it is presented unit root test for labour productivity.

\section{ADF test for productivity}

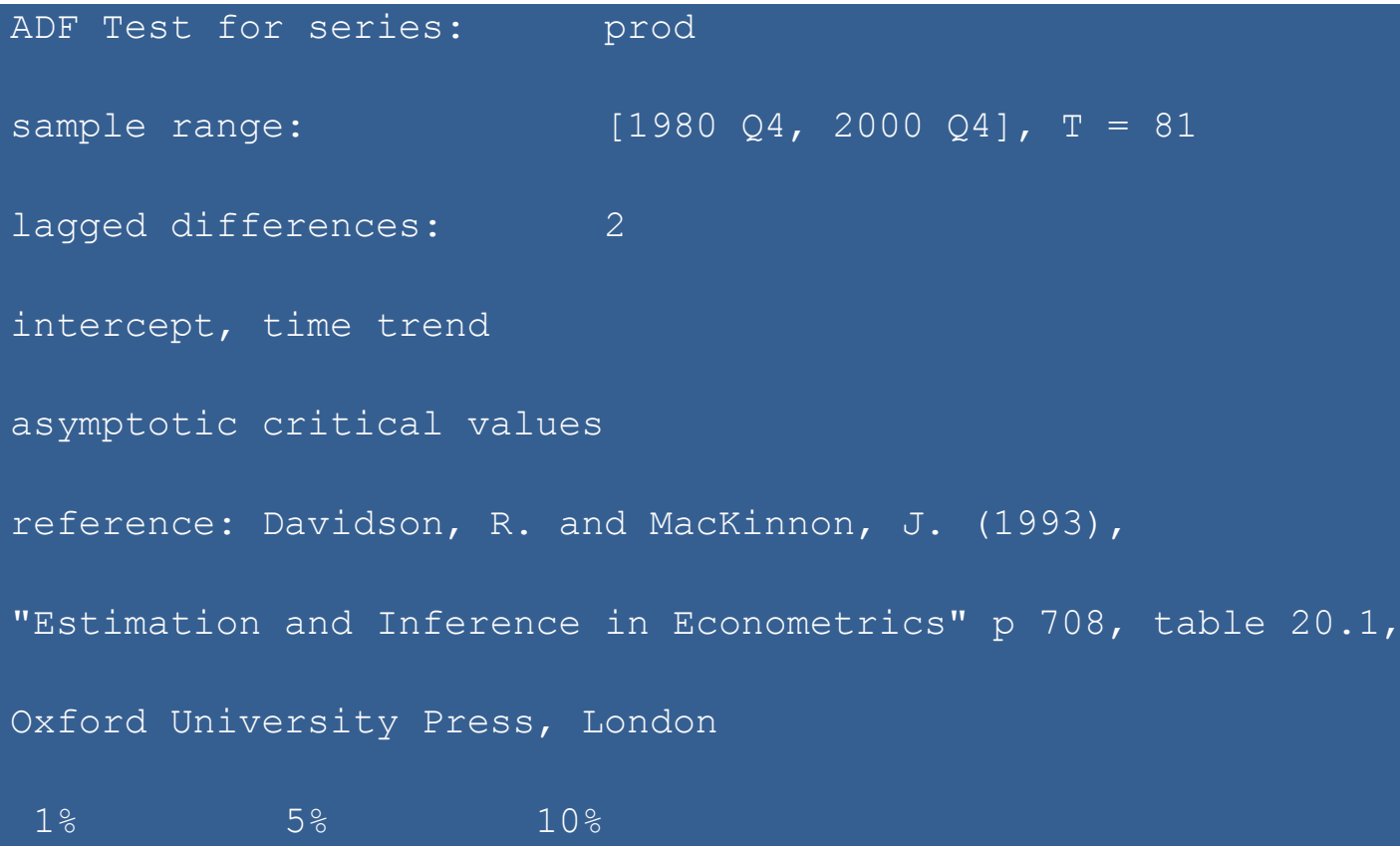




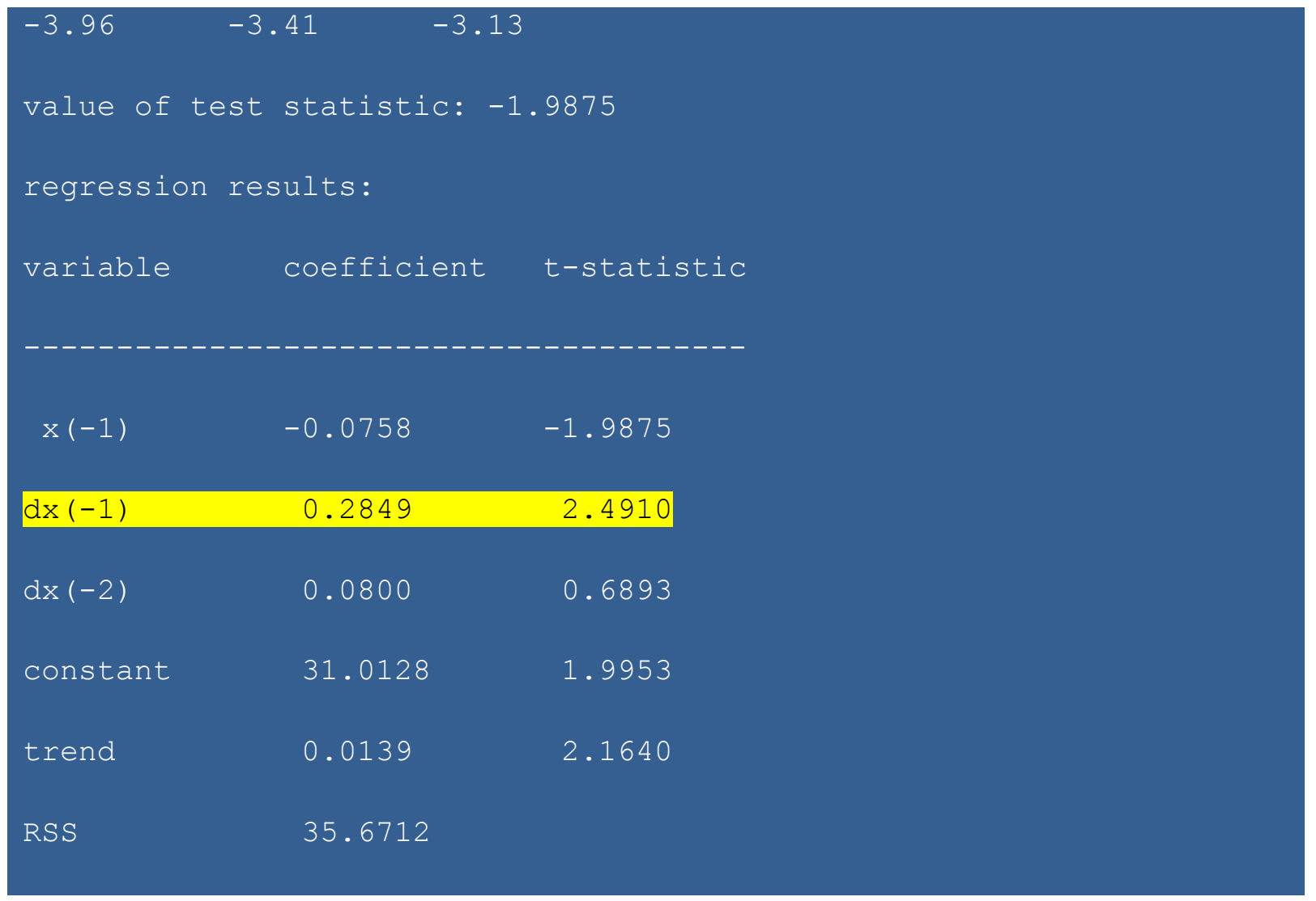

This variable has unit root and is not stationary. Optimal number of lags is 1 .

\section{OPTIMAL ENDOGENOUS LAGS FROM INFORMATION CRITERIA}

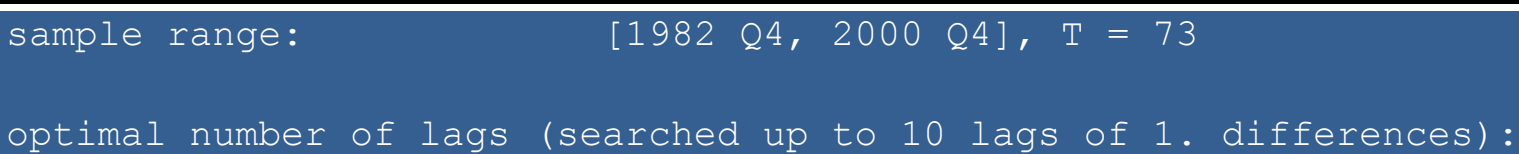

Akaike Info Criterion

Hannan-Quinn Criterion

Final Prediction Error

Schwarz Criterion

1
1
1
1

\section{Test for cointegration}

Johansens trace test showed that up to 2 lags this variable is $\mathrm{I}(0)$, and optimal number of lags is 2 . 


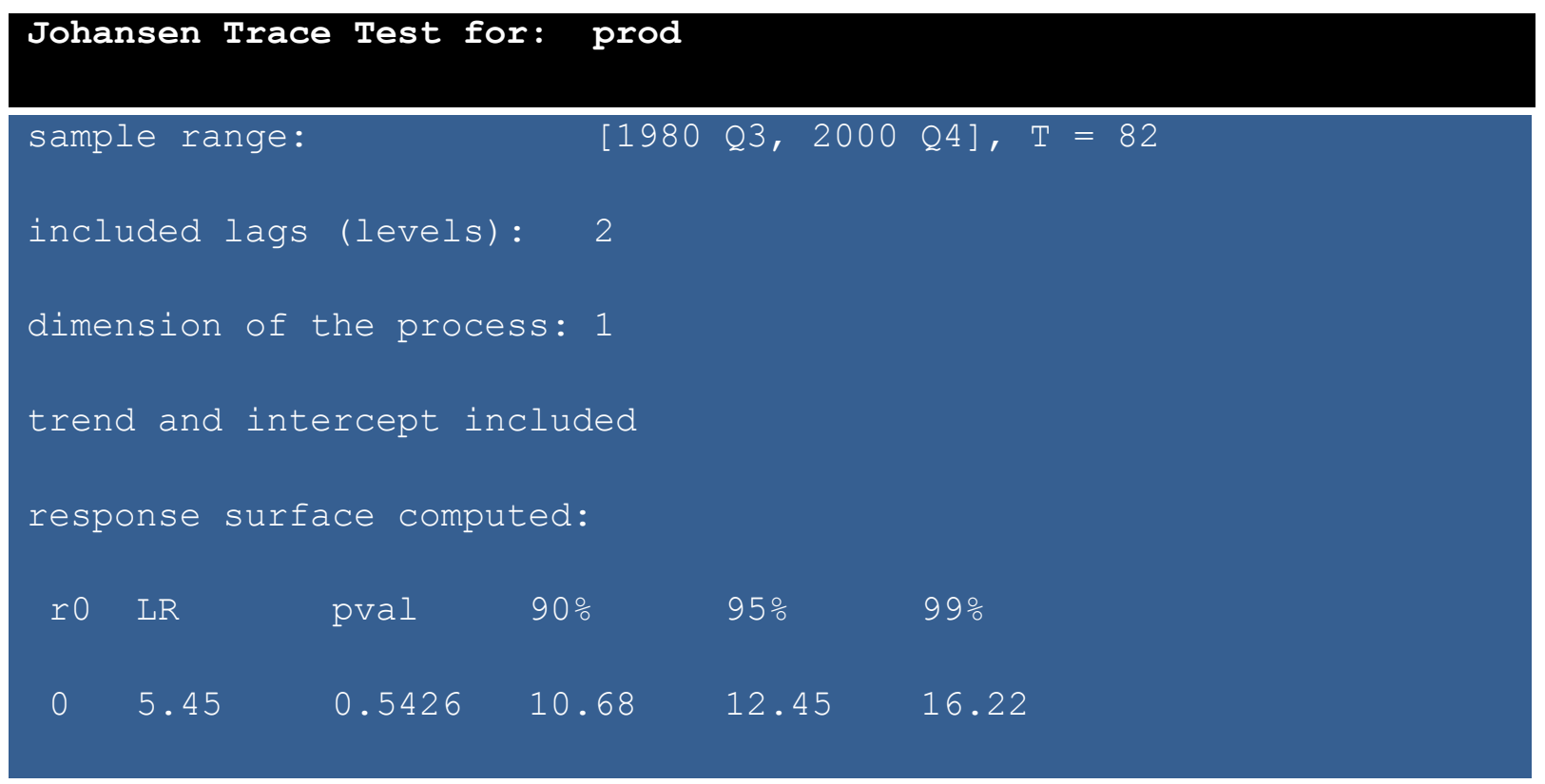

OPTIMAL ENDOGENOUS LAGS FROM INFORMATION CRITERIA

\section{OPTIMAL ENDOGENOUS IAGS FROM INFORMATION CRITERIA}

sample range: $\quad\left[\begin{array}{lll}1982 & Q 3,2000 & Q 4\end{array}\right], T=74$

optimal number of lags (searched up to 10 lags of 1 . differences):

Akaike Info Criterion

Hannan-Quinn Criterion

Final Prediction Error

Schwarz Criterion

\begin{tabular}{|l}
2 \\
2 \\
2 \\
2 \\
2
\end{tabular}




\section{$\underline{\text { ADF test for real wages }}$}

ADF test shows that this variable is not stationary and does have unit root.

ADF Test for series: rw

sample range: $\quad[1980$ Q4, 2000 Q4], T = 81

lagged differences: $\quad 2$

intercept, time trend

asymptotic critical values

reference: Davidson, R. and MacKinnon, J. (1993),

"Estimation and Inference in Econometrics" p 708, table 20.1,

Oxford University Press, London

$1 \% \quad 5 \% \quad 10 \%$

$\begin{array}{lll}-3.96 & -3.41 & -3.13\end{array}$

value of test statistic: -2.7911

regression results:

variable

coefficient $\quad$ t-statistic

$\begin{array}{lll}x(-1) & -0.0584 & -2.7911\end{array}$

$d x(-1)$

0.1835

1.6601

$d x(-2)$

$-0.0454$

$-0.4127$

constant

26.6302

2.8733

trend

0.0339

1.7741

RSS

55.6165 
OPTIMAL ENDOGENOUS LAGS FROM INFORMATION CRITERIA

OPTIMAL ENDOGENOUS LAGS FROM INFORMATION CRITERIA

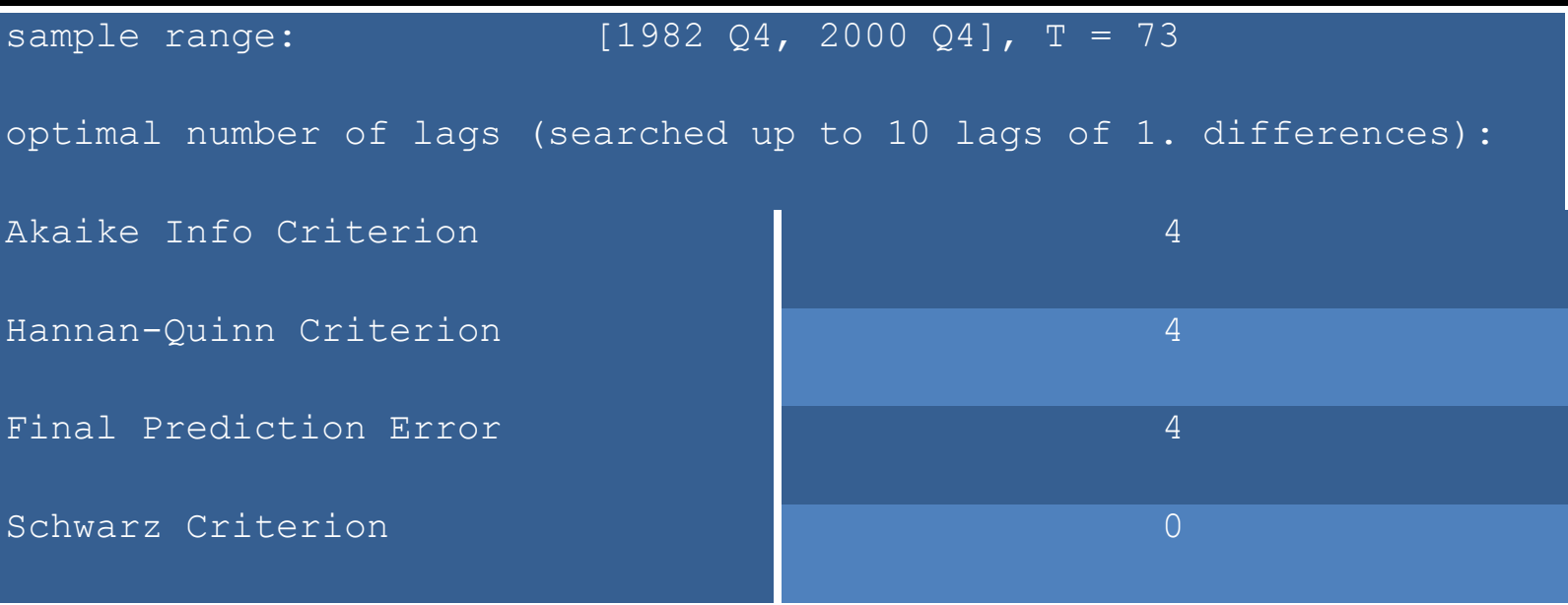

$\underline{\text { Test for cointegration }}$

Johansens trace test for variable real wages it has been conducted.

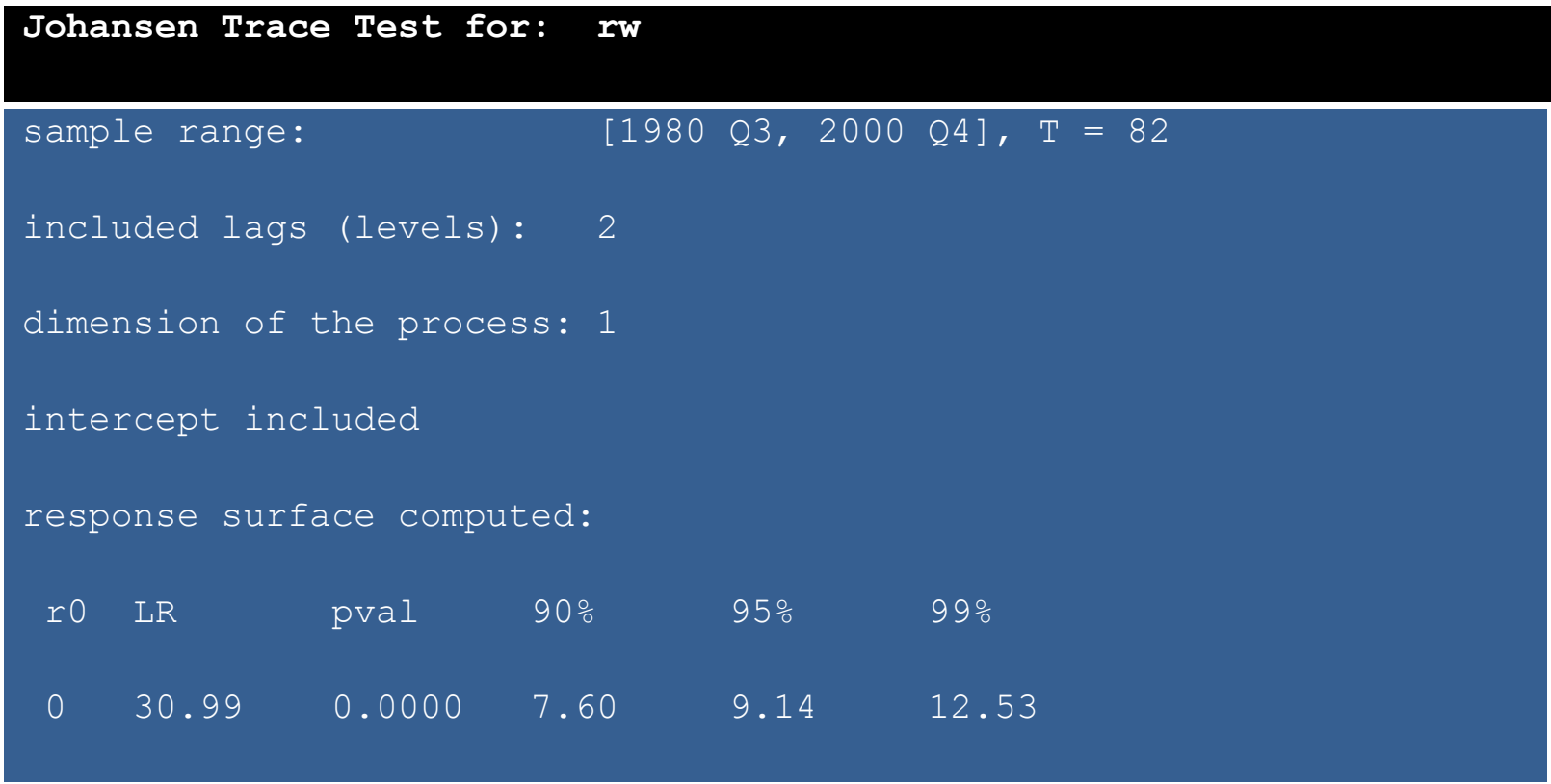




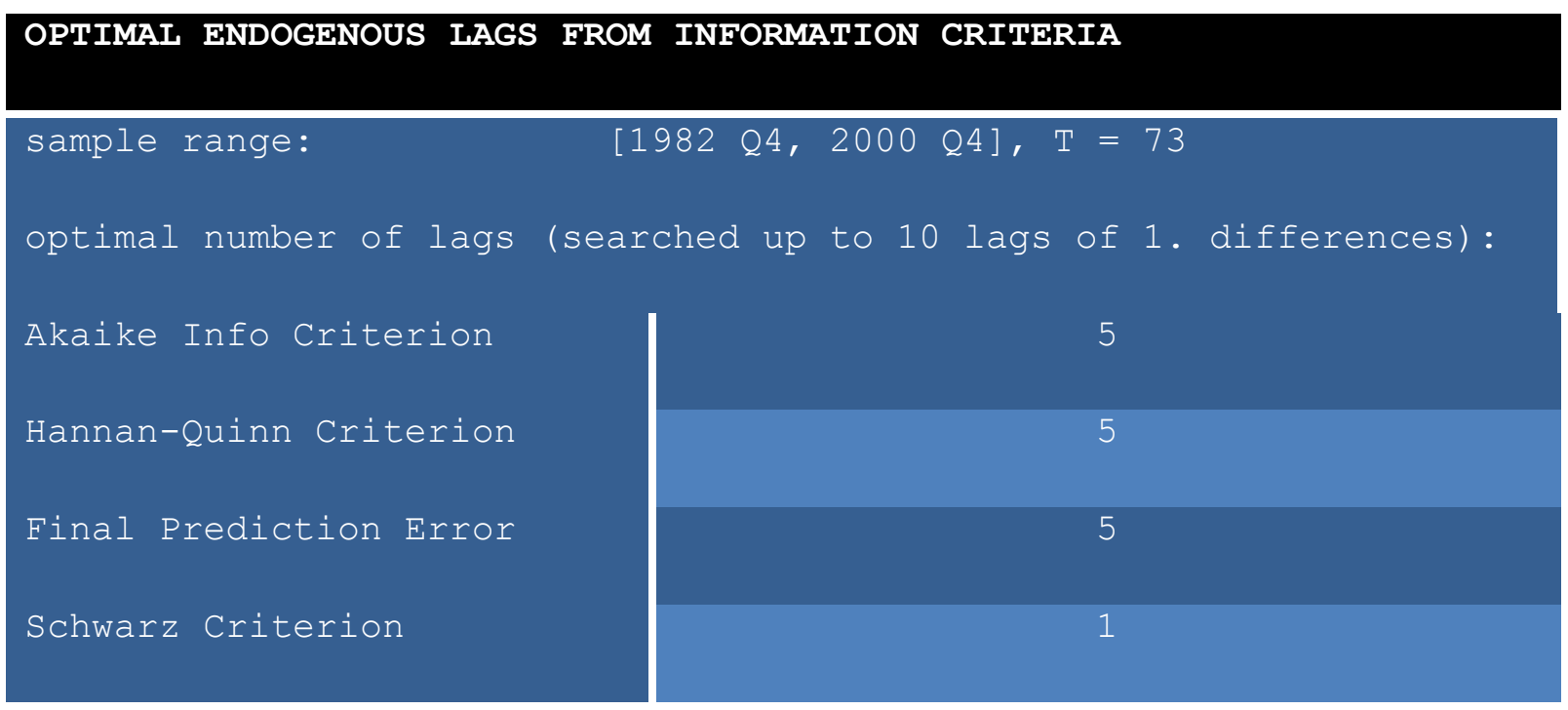

$\underline{\text { ADF test for unemployment }}$

ADF test for unemployment it has been conducted and the results are presented below.

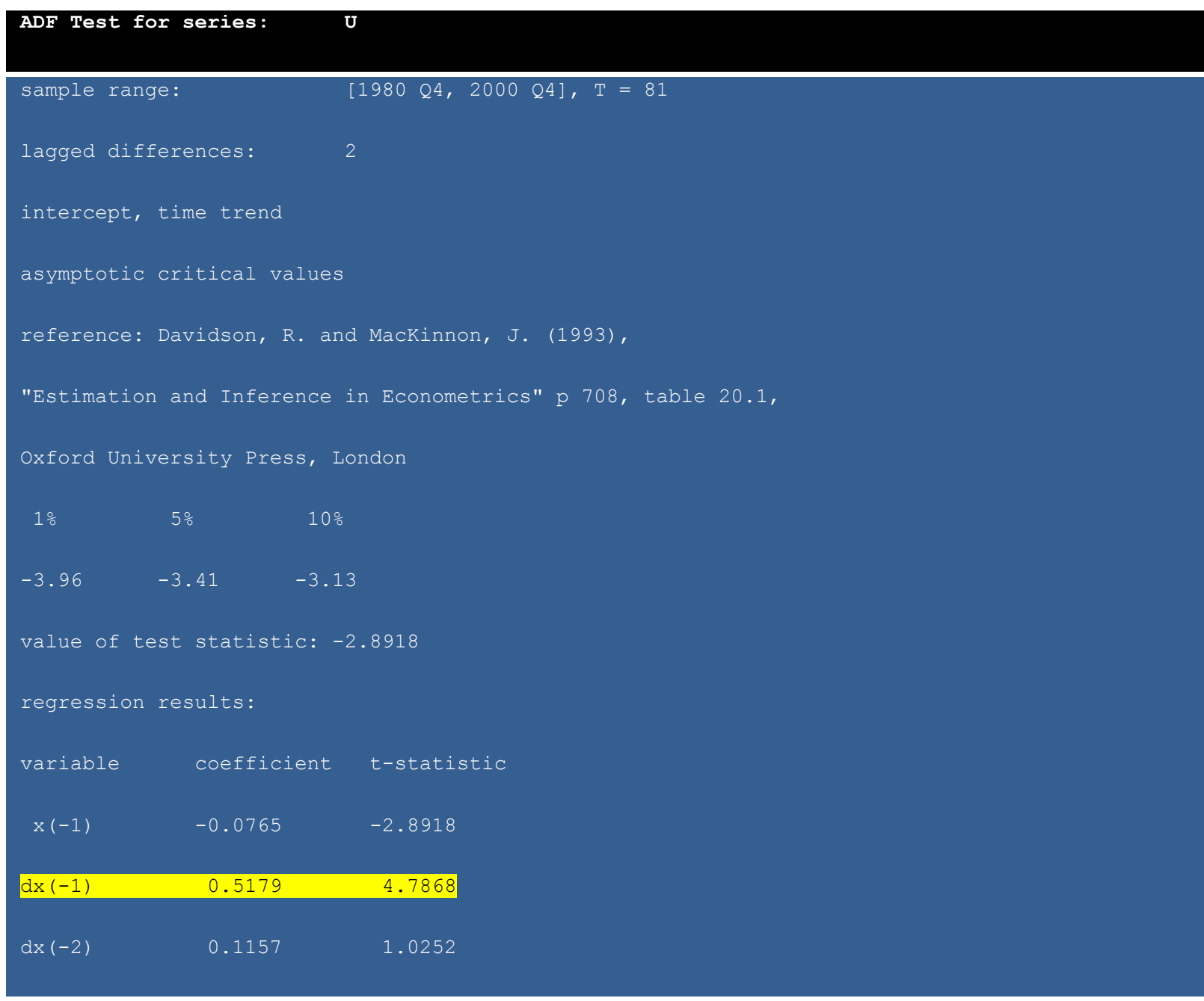




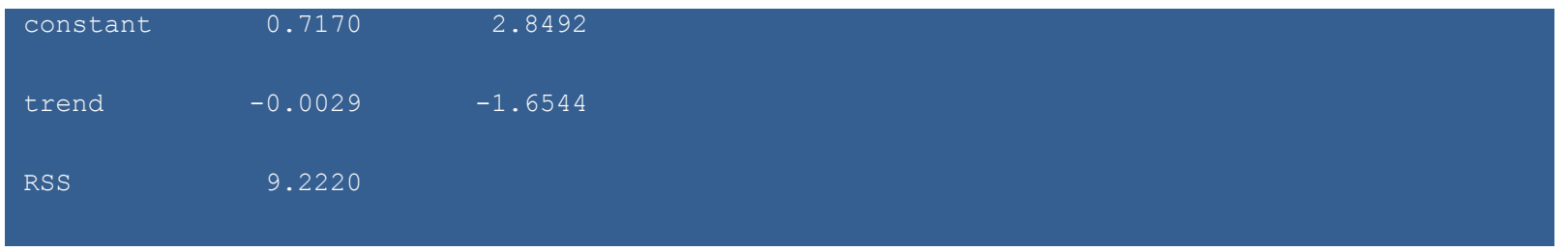

This variable is first difference stationary.

\section{OPTIMAL ENDOGENOUS IAGS FROM INEORMATION CRITERIA}

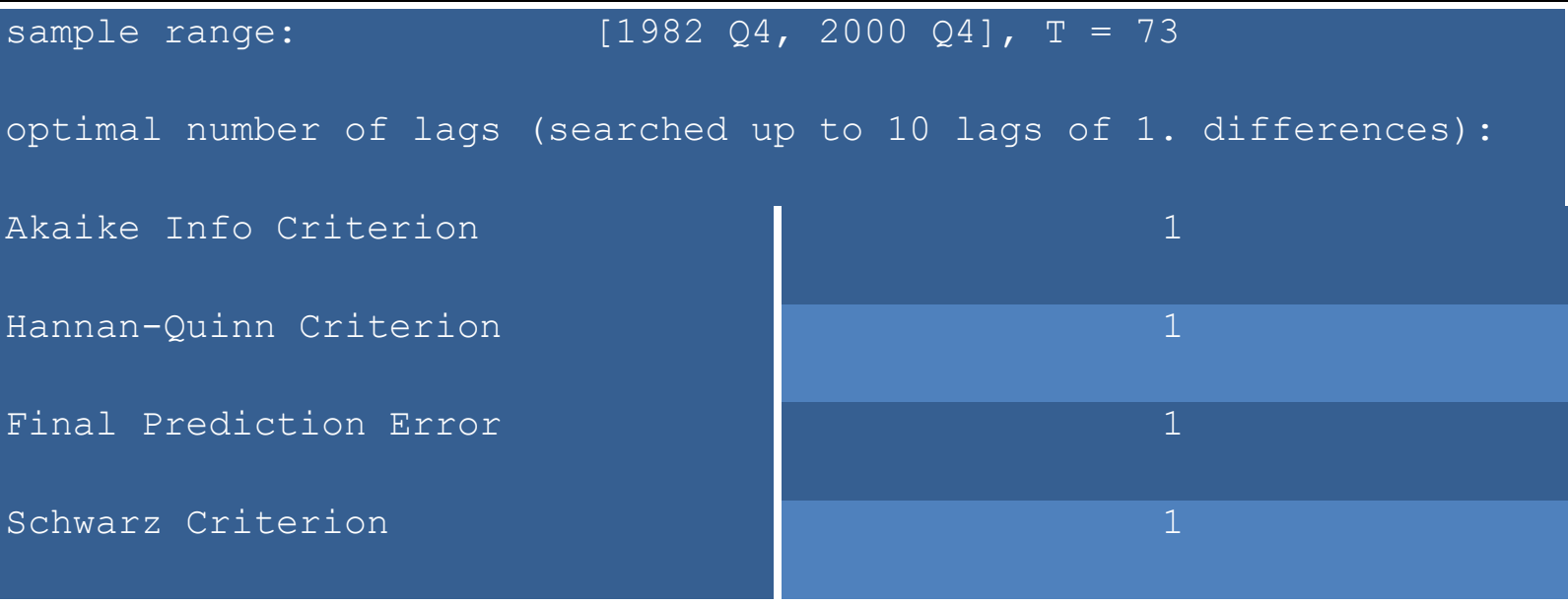

$\underline{\text { Test for cointegration }}$

Test for cointegration showed that this variables has cointegration vector $r>0$.

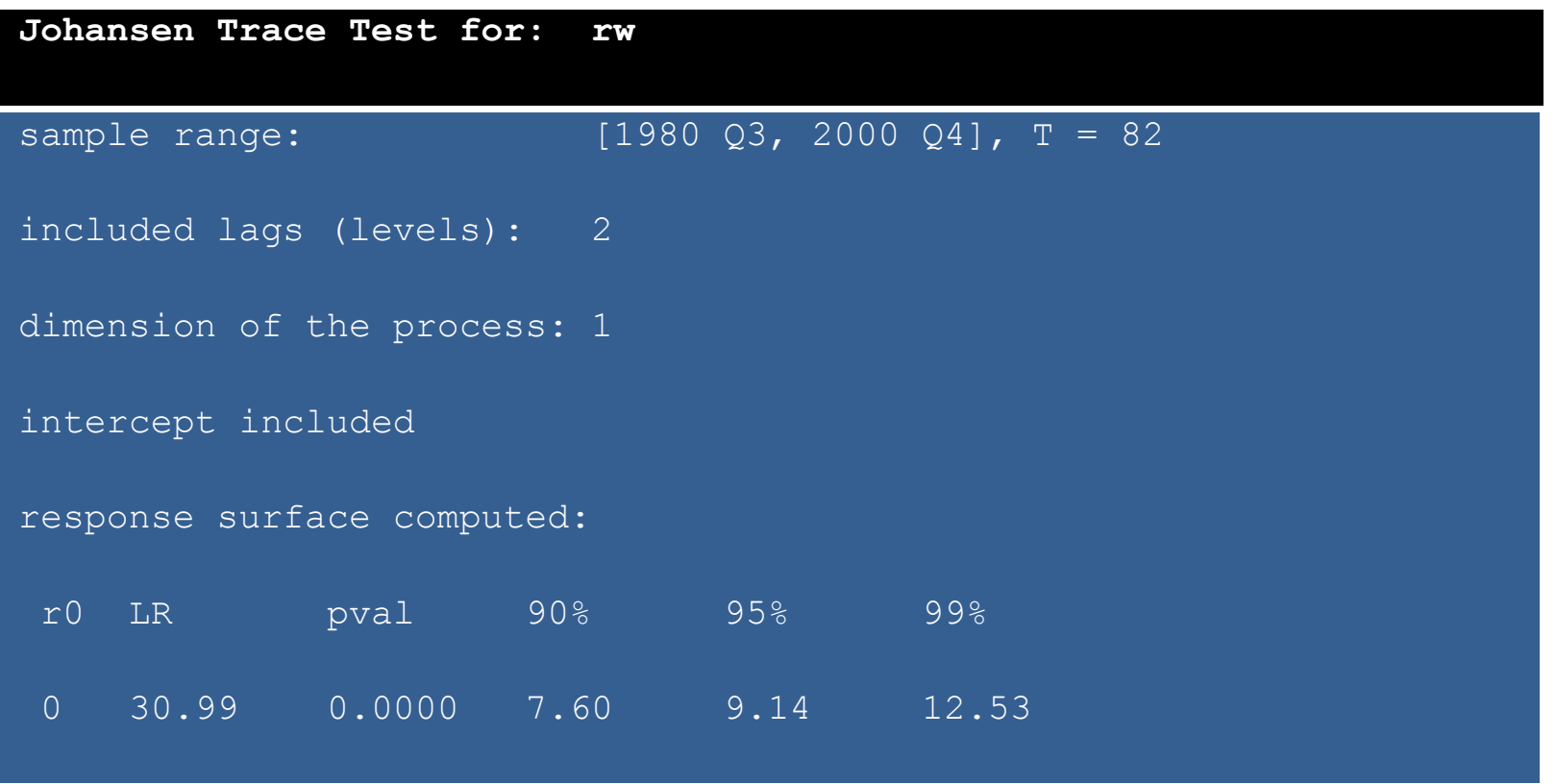




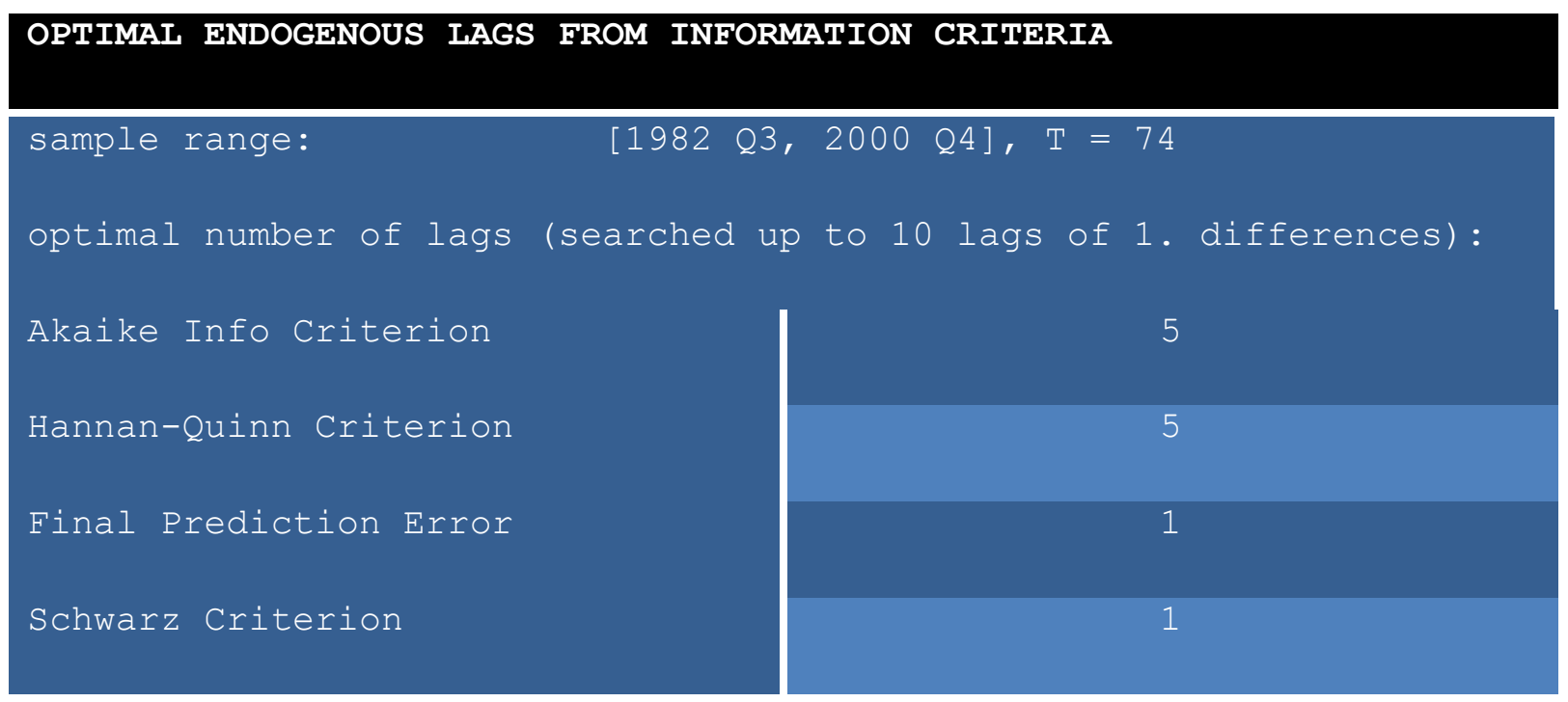

$\underline{\text { ADF test for unemployment }}$

ADF test for unemployment showed that this variable has unit root at one lag but its first difference stationary.

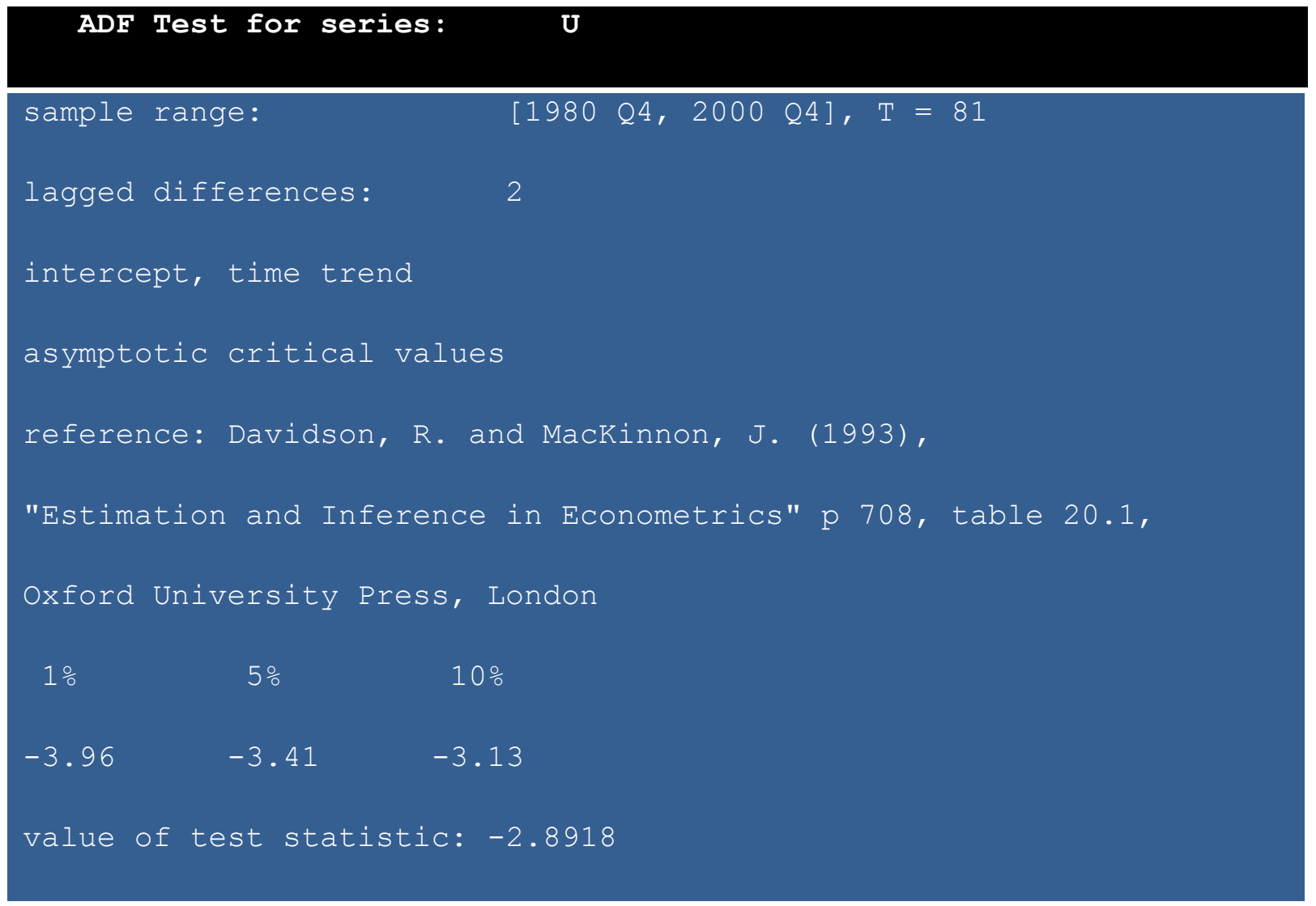




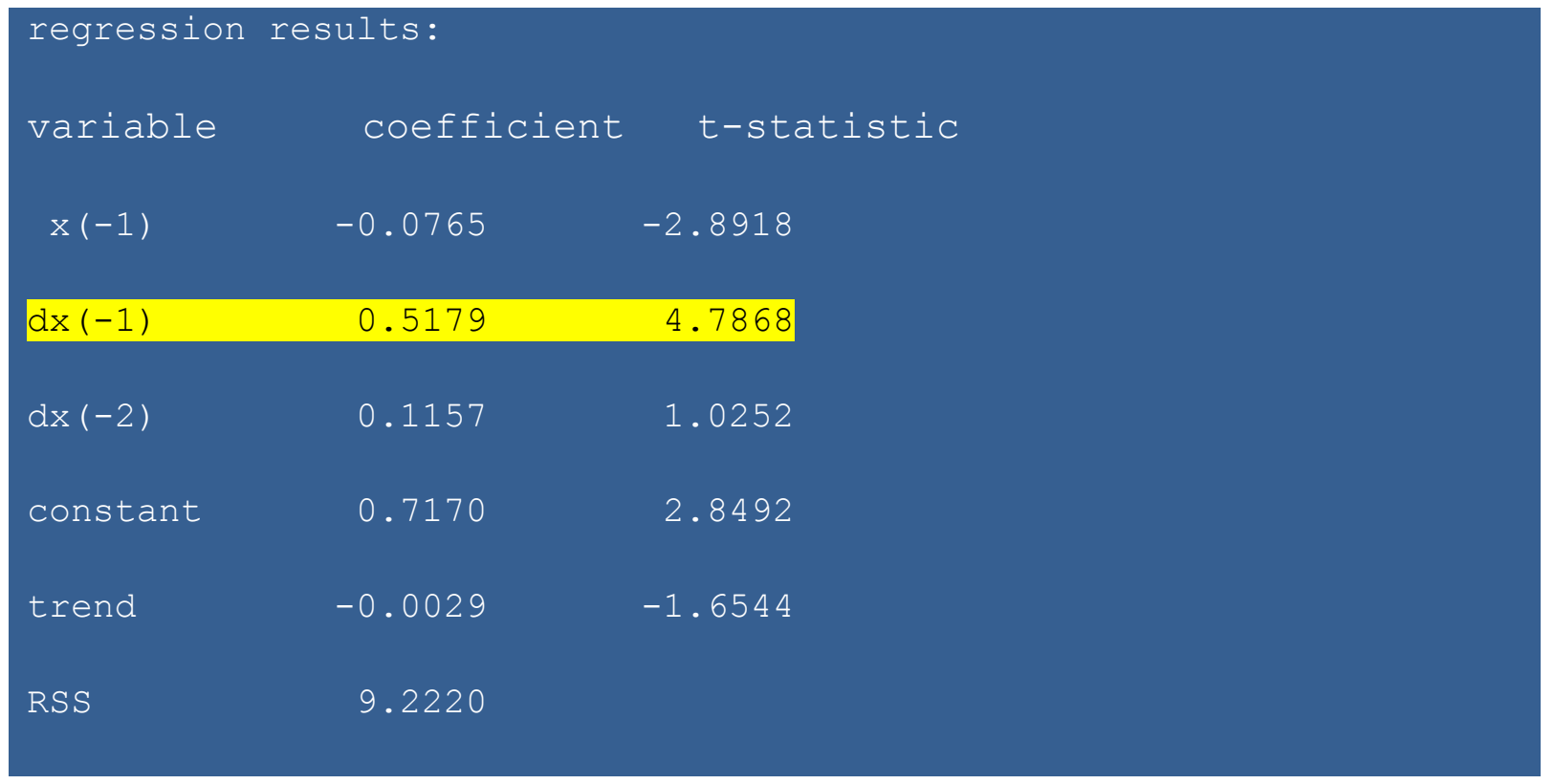

\section{OPTIMAL ENDOGENOUS IAAGS FROM INFORMATION CRITERIA}

sample range: $\quad[1982 \mathrm{Q} 4,2000 \mathrm{Q4}], \mathrm{T}=73$

optimal number of lags (searched up to 10 lags of 1 . differences):

Akaike Info Criterion

Hannan-Quinn Criterion

Final Prediction Error

Schwarz Criterion

1 
Test of cointegration for unemployment variable

Johansens trace test has been conducted for unemployment and proved that this variable is $\mathrm{I}(0)$.

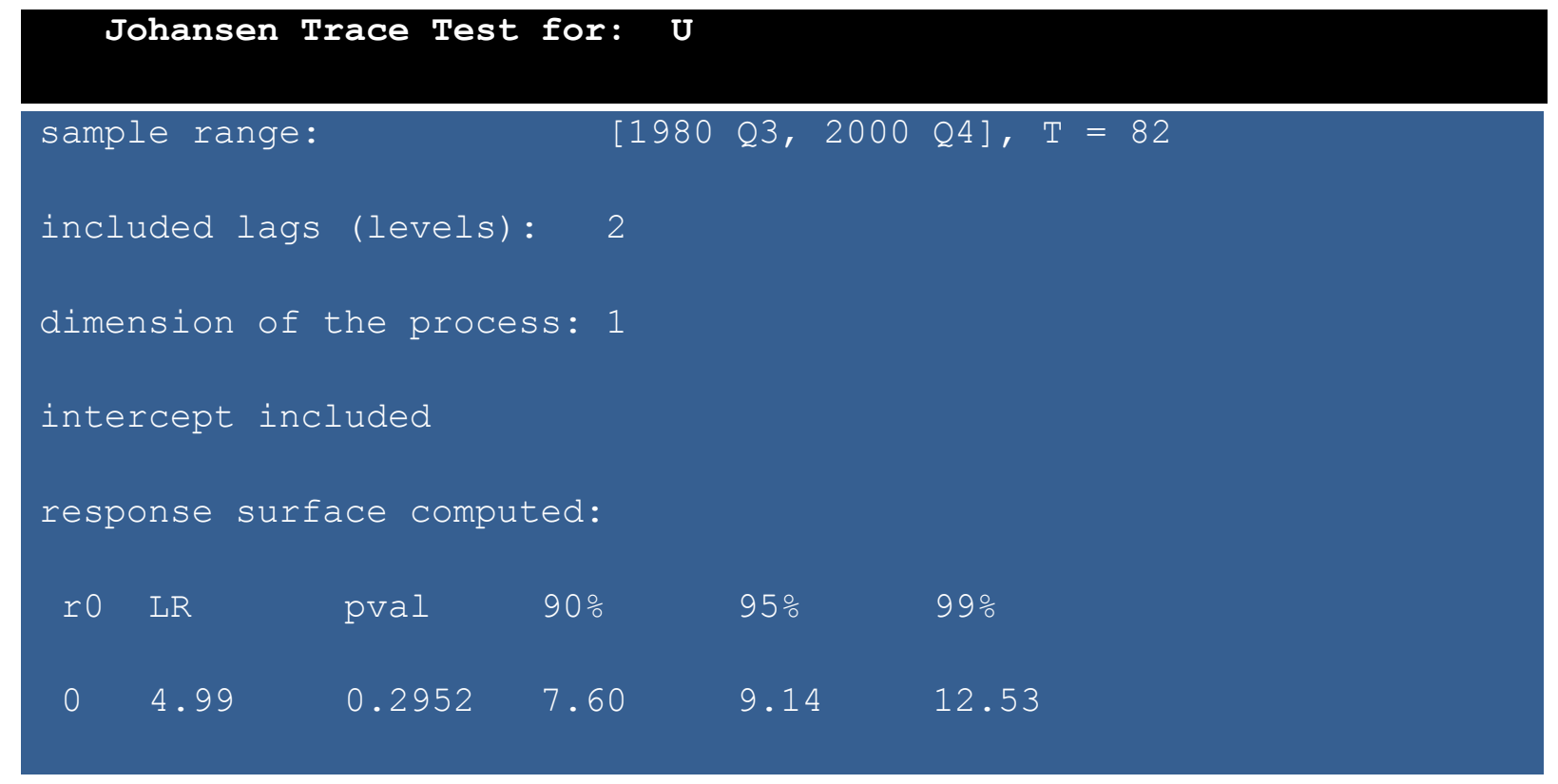

Optimal endogenous lags from info criteria is 2.

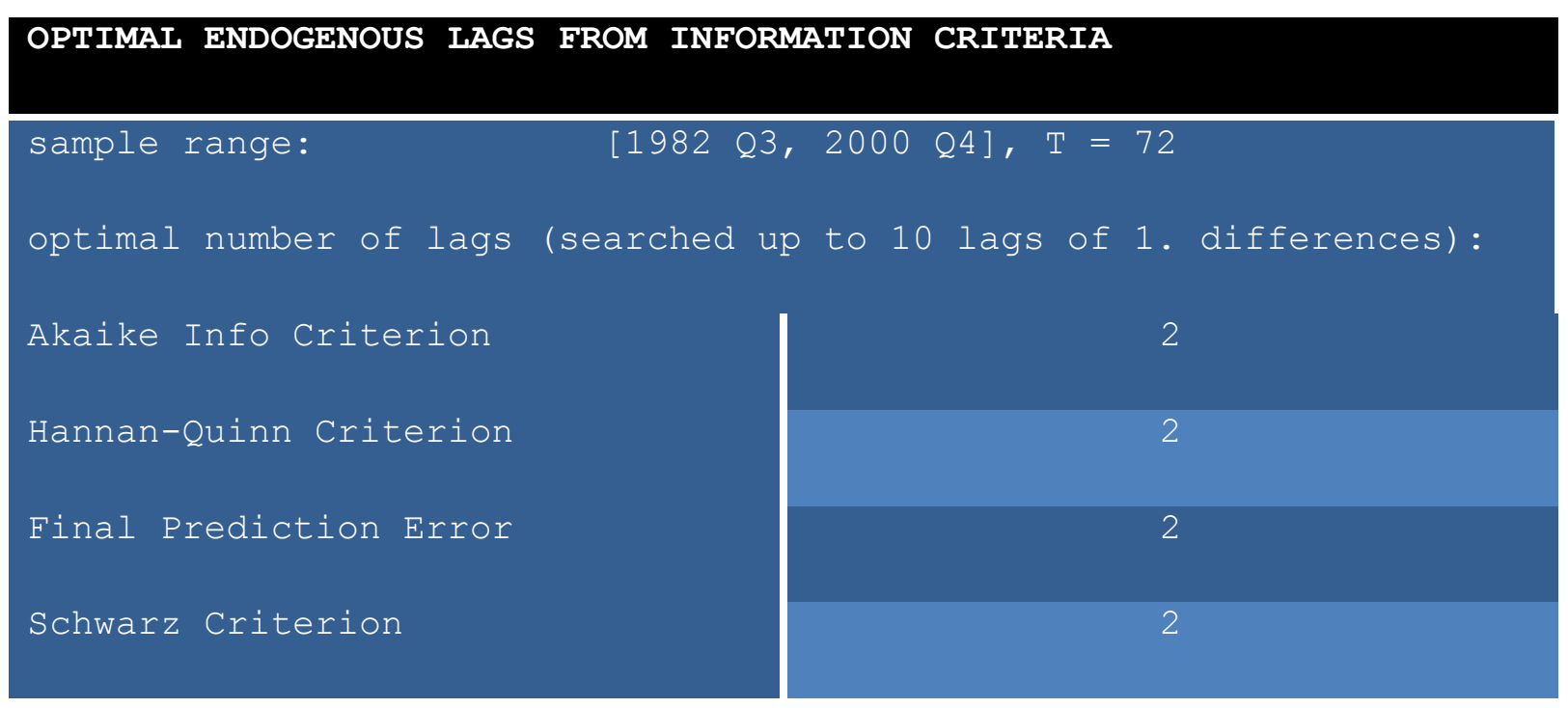


To do a VAR model first we will seek for the optimal number of lags for the model.

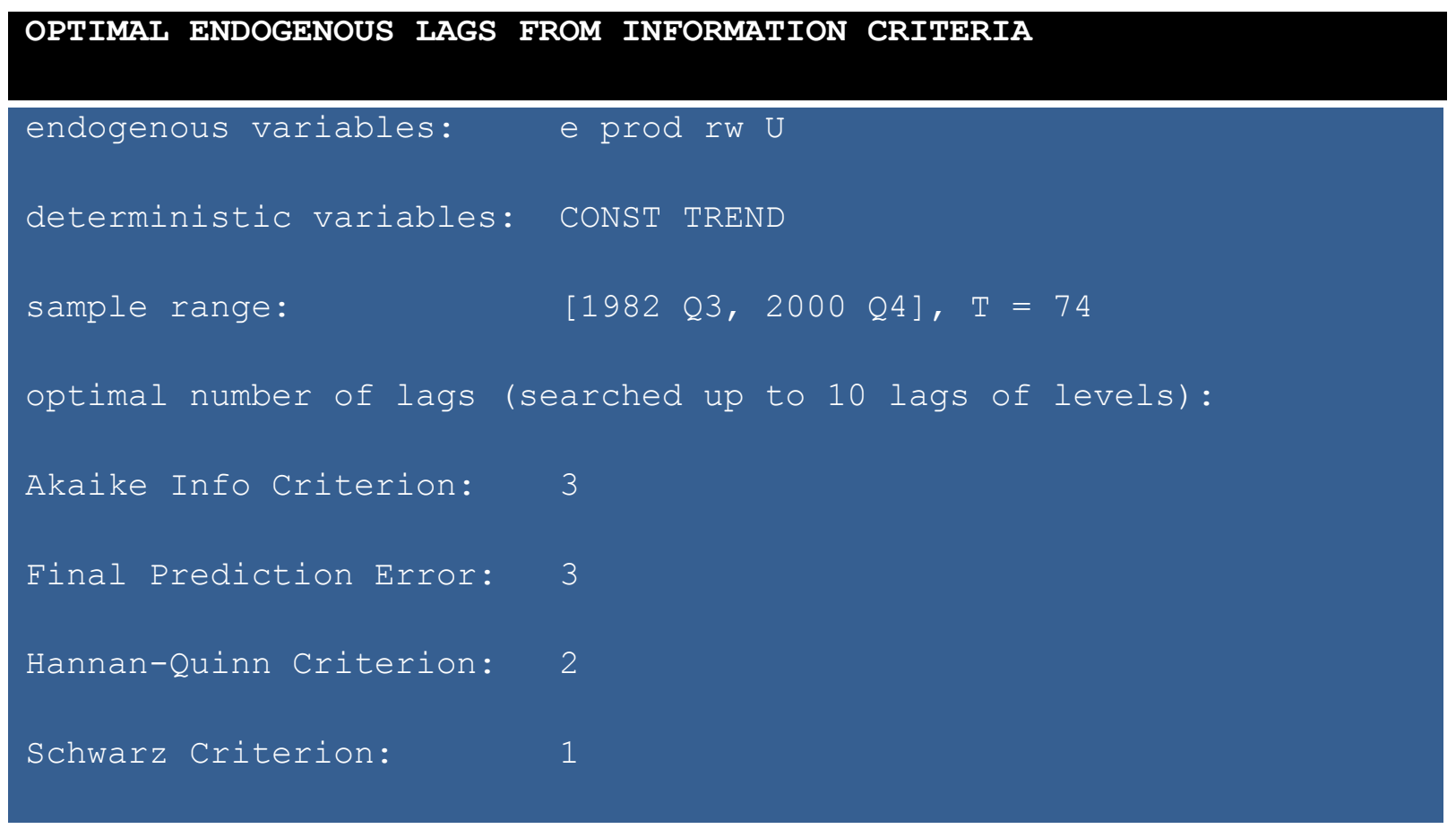

\section{VAR ESTIMATION RESULTS}

VAR estimation results are presented in a matrix form while you can look up in the Appendix 1 to see their output format. ${ }^{7}$

\footnotetext{
${ }^{7}$ See Appendix 1 VAR OUPUT FORMAT
} 


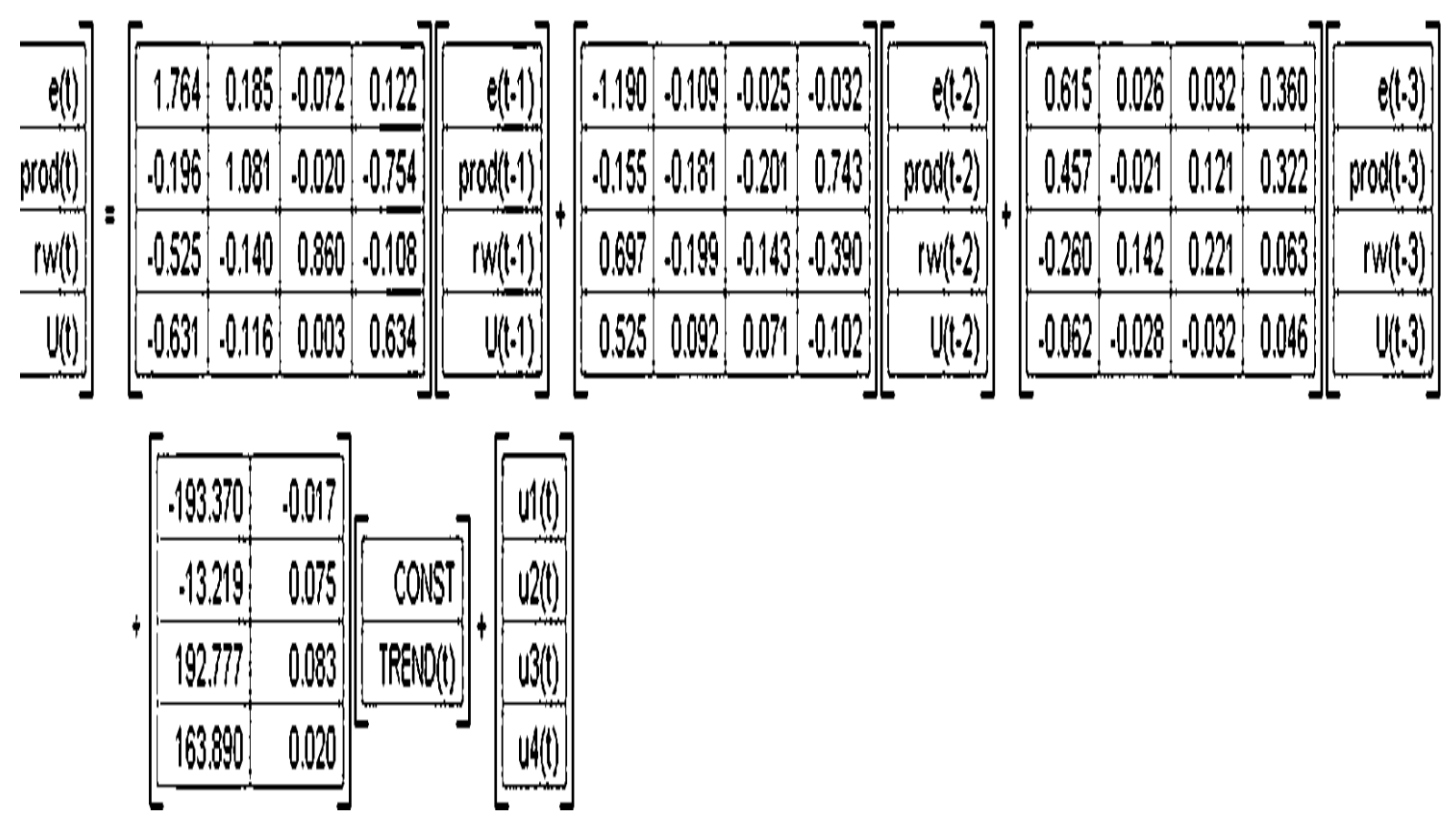

The VAR model is up to three lags since info criteria demanded that this be modeled that way.

VAR matrix coefficients are presented on the previous page.

Granger causality test

From the below table for granger causality test we can see that there is granger causality between labour productivity, employment, real wages and unemployment, but labour productivity does not granger cause three other variables.

TEST FOR GRANGER-CAUSALITY:

HO: "prod" do not Granger-cause "e, rw, U"

Test statistic $l=2.8370$ 


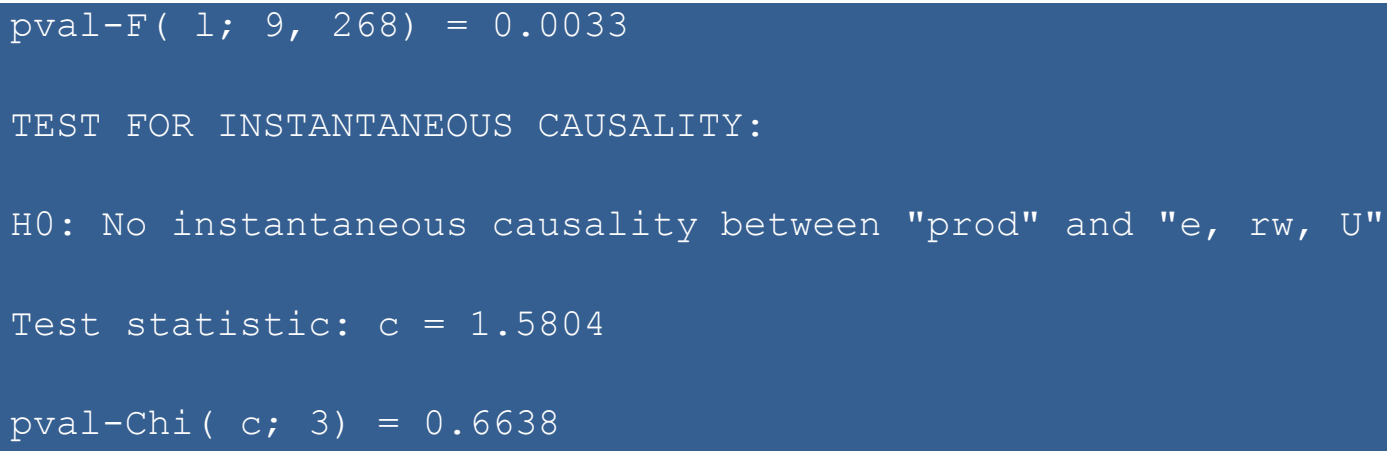

\section{VEC MODEL $^{8}$}

VEC model for Canadian time series is presented as matrix below.
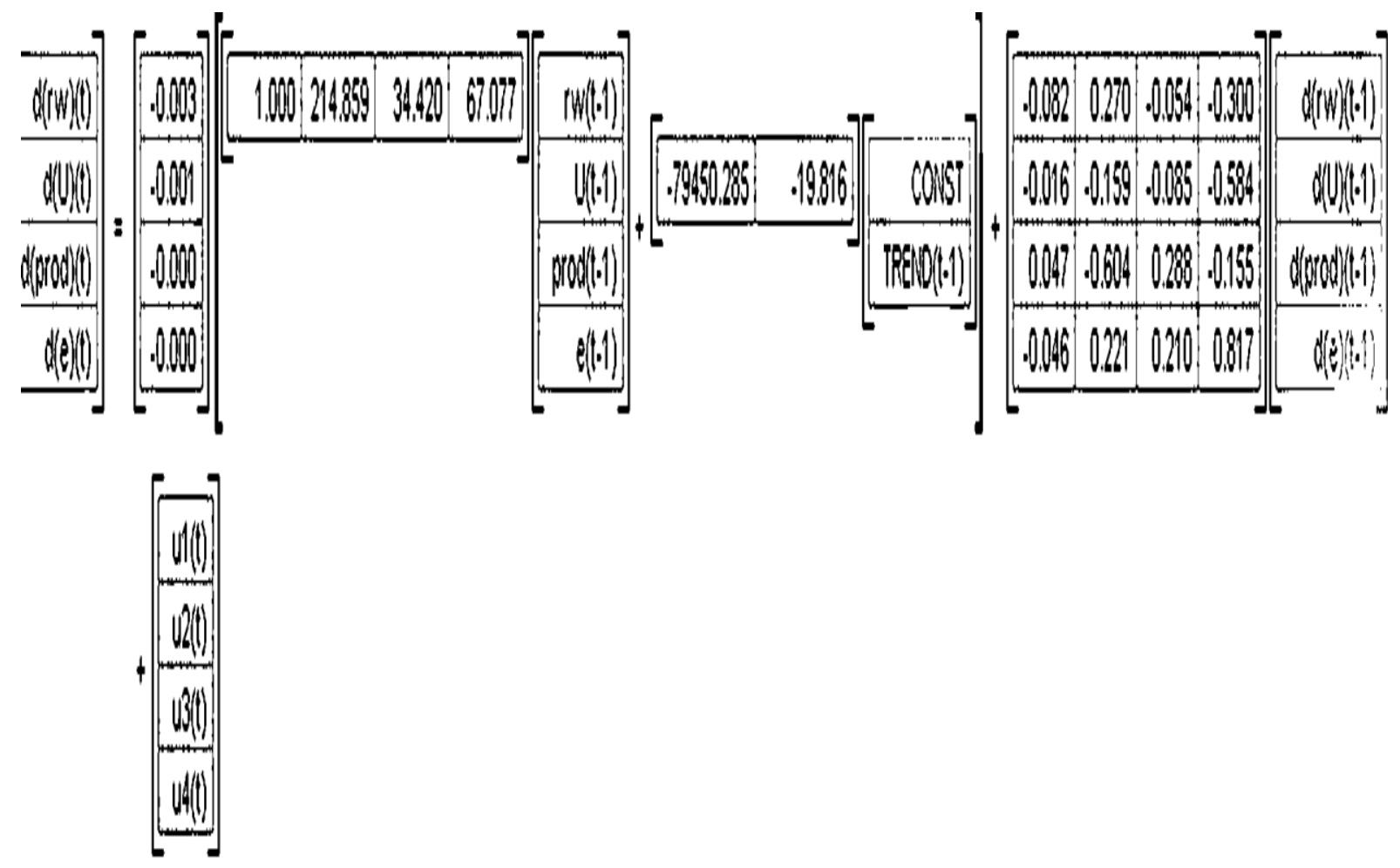

\footnotetext{
${ }^{8}$ See Appendix 2 VEC model output in jmulti
} 
VEC model shows long run coefficient, and if the system is in disequilibrium, alteration of the variables will only be -0.003 for real wages or $-0.3 \%,-0.001$ for unemployment or $-0.1 \%$, -0.000 for productivity or $-0 \%$, and $-0 \%$ for employment. This means that Canadian labour market is in equilibrium working at natural rate of unemployment and by equilibrium wages.

\section{Chow test for structural stability}

Chow test below shows that VEC model is stable according to this test.

\section{CHOW TEST FOR STRUCTURAL BRFAK}

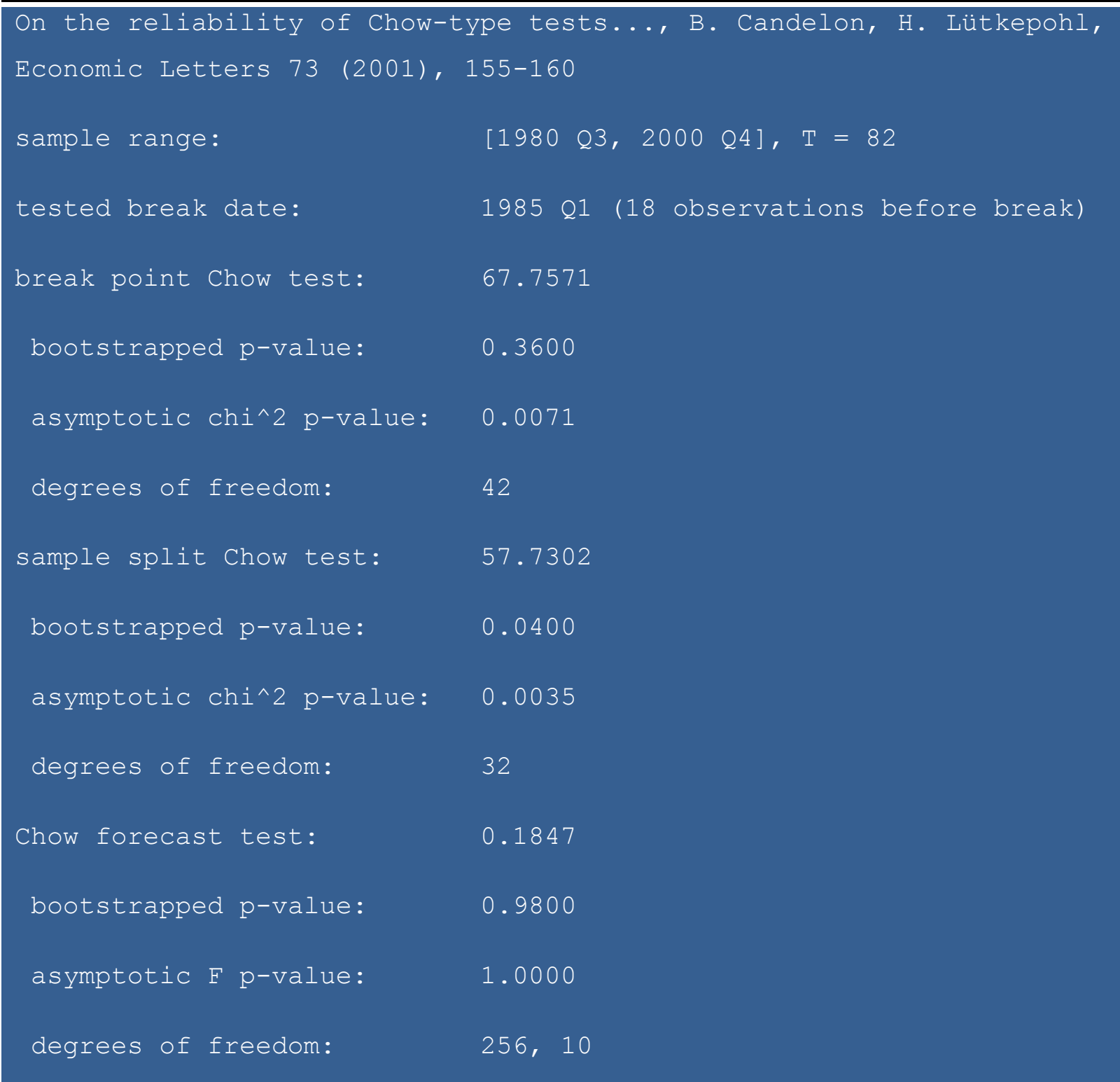


Appendix 1 VAR OUTPUT FORMAT

endogenous variables: e prod rw U

exogenous variables:

deterministic variables: CONST TREND

endogenous lags: $\quad 3$

exogenous lags: $\quad 0$

sample range: $\quad[1980$ Q4, 2000 Q4], T $=81$

modulus of the eigenvalues of the reverse characteristic polynomial :

$|z|=\left(\begin{array}{lllll}3.4351 & 1.7584 & 1.7584 & 1.6428 & 1.6428\end{array}\right.$

$\begin{array}{llllll}1.8444 & 1.8444 & 1.2214 & 1.2214 & 1.0442 & 1.0442\end{array}$

$3.8469 \quad)$

Legend:

$=====$

Equation 1 Equation $2 \quad \ldots$

Variable 1 | Coefficient

I (Std. Dev.)

I $\{\mathrm{p}-$ Value $\}$

I $[t$ - Value $]$

Variable 2 | 
Lagged endogenous term:

\begin{tabular}{|c|c|c|c|c|c|}
\hline & & e & prod & rw & $\mathrm{U}$ \\
\hline \multirow[t]{4}{*}{ e } & $(t-1)$ & 1.764 & -0.196 & -0.525 & -0.631 \\
\hline & I & $(0.151)$ & $(0.280)$ & $(0.327)$ & $(0.124)$ \\
\hline & I & $\{0.000\}$ & $\{0.483\}$ & $\{0.109\}$ & $\{0.000\}$ \\
\hline & I & {$[11.678]$} & {$[-0.702]$} & {$[-1.602]$} & {$[-5.075]$} \\
\hline \multicolumn{2}{|c|}{$\operatorname{prod}(t-1) \mid$} & 0.185 & 1.081 & -0.140 & -0.116 \\
\hline & I & $(0.064)$ & $(0.118)$ & $(0.139)$ & $(0.053)$ \\
\hline & I & $\{0.004\}$ & $\{0.000\}$ & $\{0.314\}$ & $\{0.028\}$ \\
\hline & I & {$[2.897]$} & {$[9.136]$} & {$[-1.007]$} & {$[-2.203]$} \\
\hline \multirow[t]{4}{*}{ rw } & $(t-1)$ & -0.072 & -0.020 & 0.860 & 0.003 \\
\hline & I & $(0.054)$ & $(0.099)$ & $(0.116)$ & $(0.044)$ \\
\hline & I & $\{0.177\}$ & $\{0.841\}$ & $\{0.000\}$ & $\{0.950\}$ \\
\hline & I & {$[-1.352]$} & {$[-0.201]$} & {$[7.405]$} & {$[0.062]$} \\
\hline \multirow[t]{4}{*}{$\mathrm{U}$} & $(t-1) \mid$ & 0.122 & -0.754 & -0.108 & 0.634 \\
\hline & I & $(0.198)$ & $(0.367)$ & $(0.430)$ & $(0.163)$ \\
\hline & I & $\{0.539\}$ & $\{0.040\}$ & $\{0.801\}$ & $\{0.000\}$ \\
\hline & I & {$[0.615]$} & {$[-2.053]$} & {$[-0.252]$} & {$[3.883]$} \\
\hline \multirow[t]{3}{*}{ e } & $(t-2) \mid$ & -1.190 & -0.155 & 0.697 & 0.525 \\
\hline & I & $(0.235)$ & $(0.435)$ & $(0.510)$ & $(0.193)$ \\
\hline & I & $\{0.000\}$ & $\{0.722\}$ & $\{0.171\}$ & $\{0.007\}$ \\
\hline
\end{tabular}




$$
\begin{aligned}
& \mid\left[\begin{array}{llll}
-5.064] & {[-0.356]} & {[1.367]} & {[2.717]}
\end{array}\right. \\
& \begin{array}{lllll}
\operatorname{prod}(t-2) \mid & -0.109 & -0.181 & -0.199 & 0.092
\end{array} \\
& \begin{array}{lllll}
1 & (0.094) & (0.174) & (0.204) & (0.078)
\end{array} \\
& \mid\{0.246\} \quad\{0.300\} \quad\{0.330\} \quad\{0.234\} \\
& \mid\left[\begin{array}{llll}
-1.161] & {[-1.036]} & {[-0.975]} & {[1.189]}
\end{array}\right. \\
& \begin{array}{llllll}
r w & (t-2) \mid & -0.025 & -0.201 & -0.143 & 0.071
\end{array} \\
& \begin{array}{lllll} 
& (0.070) & (0.129) & (0.151) & (0.057)
\end{array} \\
& \text { I }\{0.720\} \quad\{0.118\} \quad\{0.342\} \quad\{0.218\} \\
& \mid \begin{array}{lllll} 
& {[-0.358]} & {[-1.564]} & {[-0.951]} & {[1.233]}
\end{array} \\
& \begin{array}{llllll}
\mathrm{U} & (\mathrm{t}-2) \mid & -0.032 & 0.743 & -0.390 & -0.102
\end{array} \\
& \begin{array}{llll}
(0.246) \quad(0.455) \quad(0.533) \quad(0.202) & 0
\end{array} \\
& \mid\{0.895\} \quad\{0.102\} \quad\{0.464\} \quad\{0.612\} \\
& \mid[-0.131] \quad[1.634] \quad[-0.732] \quad[-0.507] \\
& \begin{array}{llllll}
e & (t-3) \mid & 0.615 & 0.457 & -0.260 & -0.062
\end{array} \\
& \begin{array}{lllll}
1 & (0.166) & (0.308) & (0.360) & (0.137)
\end{array} \\
& \mid\{0.000\} \quad\{0.137\} \quad\{0.470\} \quad\{0.651\} \\
& \text { I [3.699] [1.487] [-0.723] [-0.453] }
\end{aligned}
$$$$
\operatorname{prod}(t-3) \mid \quad 0.026 \quad-0.021 \quad 0.142 \quad-0.028
$$$$
\begin{array}{llll}
(0.065) \quad(0.121) \quad(0.142) \quad(0.054)
\end{array}
$$$$
\mid\{0.695\} \quad\{0.865\} \quad\{0.318\} \quad\{0.597\}
$$$$
\text { I [0.392] [-0.169] [0.999] [-0.529] }
$$

$$
\begin{array}{llllll}
r w & (t-3) \mid & 0.032 & 0.121 & 0.221 & -0.032
\end{array}
$$$$
\begin{array}{lllll}
1 & (0.054) & (0.100) & (0.117) & (0.044)
\end{array}
$$$$
\mid\{0.557\} \quad\{0.225\} \quad\{0.058\} \quad\{0.477\}
$$ 


$\begin{array}{ccccc}\mid & {[0.588]} & {[1.214]} & {[1.893]} & {[-0.711]} \\ \mathrm{U} \quad(t-3) \mid & 0.360 & 0.322 & 0.063 & 0.046 \\ \mid & (0.206) & (0.381) & (0.446) & (0.169) \\ \mid & {[1.748]} & {[0.845]} & {[0.140]} & {[0.269]}\end{array}$

Deterministic term:

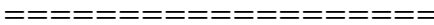

e prod rw $\quad$ U

\begin{tabular}{|c|c|c|c|c|c|}
\hline \multirow[t]{4}{*}{ CONST } & I & -193.370 & -13.219 & 192.777 & 163.890 \\
\hline & | & $(73.005)$ & $(135.180)$ & $(158.276)$ & $(60.057)$ \\
\hline & | & $\{0.008\}$ & $\{0.922\}$ & $\{0.223\}$ & $\{0.006\}$ \\
\hline & 1 & {$[-2.649]$} & {$[-0.098]$} & {$[1.218]$} & {$[2.729]$} \\
\hline
\end{tabular}

$\operatorname{TREND}(t) \mid \quad-0.017 \quad 0.075 \quad 0.083 \quad 0.020$

$\begin{array}{lllll}1 & (0.016) \quad(0.030) & (0.036) \quad(0.013)\end{array}$

$\mid\{0.288\} \quad\{0.014\} \quad\{0.019\} \quad\{0.134\}$

$\mid[-1.062] \quad[2.455] \quad[2.347] \quad[1.498]$

Appendix 2 VEC model

VEC REPRESENTATION

endogenous variables: rw U prod e

exogenous variables:

deterministic variables: CONST TREND 
endogenous lags (diffs): 1

exogenous lags: 0

sample range: $\quad[1980$ Q3, 2000 Q4], $\mathrm{T}=82$

estimation procedure: One stage. Johansen approach

Lagged endogenous term:

\begin{tabular}{|c|c|c|c|c|c|}
\hline & & $d(r w)$ & $d(U)$ & $d($ prod) & $d(e)$ \\
\hline \multirow[t]{4}{*}{$d(r w)$} & $(t-1) \mid$ & -0.082 & -0.016 & 0.047 & -0.046 \\
\hline & । & $(0.110)$ & $(0.043)$ & $(0.099)$ & $(0.057)$ \\
\hline & । & $\{0.457\}$ & $\{0.714\}$ & $\{0.636\}$ & $\{0.416\}$ \\
\hline & । & {$[-0.744]$} & {$[-0.366]$} & {$[0.473]$} & {$[-0.814]$} \\
\hline \multirow[t]{4}{*}{$d(U)$} & $(t-1) \mid$ & 0.270 & -0.159 & -0.604 & 0.221 \\
\hline & । & $(0.368)$ & $(0.143)$ & $(0.334)$ & $(0.190)$ \\
\hline & । & $\{0.463\}$ & $\{0.266\}$ & $\{0.070\}$ & $\{0.245\}$ \\
\hline & । & {$[0.733]$} & {$[-1.112]$} & {$[-1.810]$} & [1.164] \\
\hline \multirow[t]{4}{*}{$d$ (prod) } & $(t-1) \mid$ & -0.054 & -0.085 & 0.288 & 0.210 \\
\hline & । & $(0.118)$ & $(0.046)$ & $(0.107)$ & $(0.061)$ \\
\hline & । & $\{0.647\}$ & $\{0.063\}$ & $\{0.007\}$ & $\{0.001\}$ \\
\hline & । & {$[-0.458]$} & {$[-1.863]$} & {$[2.685]$} & [3.460] \\
\hline \multirow[t]{2}{*}{$d(e)$} & $(t-1) \mid$ & -0.300 & -0.584 & -0.155 & 0.817 \\
\hline & 1 & $(0.264)$ & $(0.102)$ & $(0.239)$ & $(0.136)$ \\
\hline
\end{tabular}




$\begin{array}{crrrr}\mid & \{0.254\} & \{0.000\} & \{0.516\} & \{0.000\} \\ \mid & {[-1.140]} & {[-5.709]} & {[-0.649]} & {[6.014]}\end{array}$

Loading coefficients:

\begin{tabular}{|c|c|c|c|c|}
\hline & $d(r w)$ & $d(U)$ & $d($ prod) & $d(e)$ \\
\hline $\operatorname{ecc}(t-1) \mid$ & -0.003 & -0.001 & 0.000 & 0.000 \\
\hline | & $(0.000)$ & $(0.000)$ & $(0.000)$ & $(0.000)$ \\
\hline | & $\{0.000\}$ & $\{0.000\}$ & $\{0.768\}$ & $\{0.416\}$ \\
\hline | & {$[-7.568]$} & {$[-3.886]$} & {$[-0.295]$} & {$[-0.813]$} \\
\hline
\end{tabular}

Estimated cointegration relation(s):

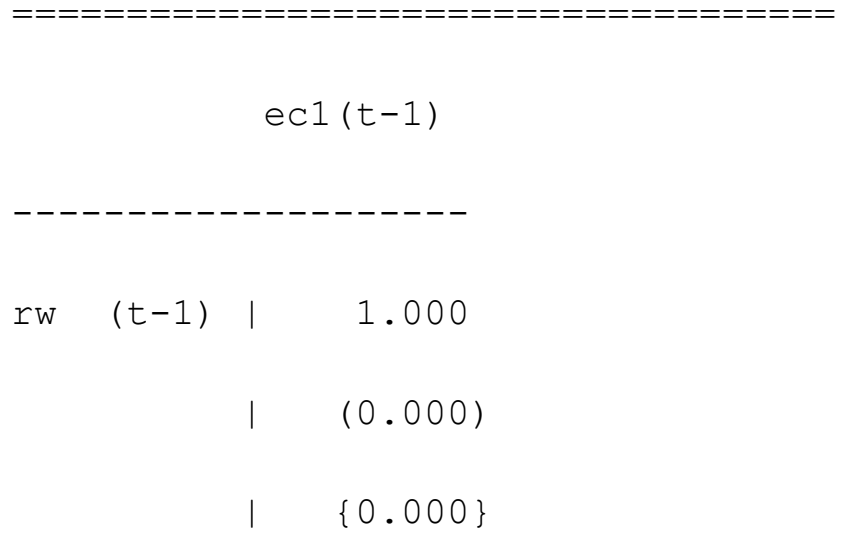




$$
\begin{array}{rrr} 
& {[} & {[0.000]} \\
U \quad(t-1) & \mid & 214.859 \\
& & (44.981) \\
& & \{0.000\} \\
& & {[4.777]}
\end{array}
$$

$\operatorname{prod}(t-1) \quad \mid \quad 34.420$

$$
\begin{aligned}
& \text { I (19.716) } \\
& \text { । }\{0.081\} \\
& \text { I [1.746] } \\
& \text { e }(t-1) \quad \mid \quad 67.077 \\
& \text { I (22.682) } \\
& 1 \quad\{0.003\} \\
& \text { I [2.957] }
\end{aligned}
$$

CONST | $\quad-79450.285$

| (26488.658)

I $\{0.003\}$

$$
\text { । }[-2.999]
$$

$\operatorname{TREND}(t-1) \mid \quad-19.816$

$$
\text { I (9.336) }
$$

| $\{0.034\} \quad[-2.123]$


1. Steven J. Davis \& R. Jason Faberman \& John Haltiwanger, 2006. "The Flow Approach to Labor Markets: New Data Sources and Micro-Macro Links," Journal of Economic Perspectives, American Economic Association, vol. 20(3), pages 3-26, Summer.

2. Blanchard, Oliver J. and Peter Diamond. 1990. "The Cyclical Behavior of the Gross Flows of U.S. Workers.” Brookings Papers on Economic Activity. 1990:2, pp. 85155

3. Burgess, Simon, Julia I. Lane and David Stevens. 2000. "Job flows, Worker Flows, and Churning." Journal of Labor Economics. 18:3, pp. 473-502

4. OECD Data base

5. Lütkepohl,Helmut \& Krätzig,Markus (ed.), 2004. "Applied Time Series Econometrics," Cambridge Books, Cambridge University Press, number 9780521839198.

6. Lütkepohl, Helmut \& POSKITT, D.S., 1996. "Testing for Causation Using Infinite Order Vector Autoregressive Processes," Econometric Theory, Cambridge University Press, vol. 12(01), pages 61-87, March

7. Introductory Econometrics: A Modern Approach, Jeffrey M. Wooldridge, SouthWestern College 